\title{
İlk Müslüman Hâkimiyetinden Abbasilere Müslümanların Güney Kafkasya Politikalarına Etki Eden İç ve Dış Gelişmeler
}

\author{
Bayram Arif Köse*
}

\begin{abstract}
Özet
Güney Kafkasya olarak adlandırılan Azerbaycan, Ermeniye ve Arran coğrafyası, Hz. Ömer döneminde Sâsânî arazilerinin ele geçirilmesinin hemen ardından Müslüman fatihlerin faaliyet sahası içerisine girmiştir. Müslümanları buraya çeken sebeplerin başında Doğu Roma'nın Kafkas halkına uygulamış olduğu sert politikaların yanı sıra bölgede Müslümanlar aleyhine askeri faaliyetlere girişmesi olmuştu. Bununla birlikte Sâsânîlerle olan savaşlarda bölge halkından özellikle Ermenilerin kalabalık birliklerle Sâsânî ordularına destek veriyor olması da Müslümanları buraya çeken sebepler arasında gösterilebilmektedir. Kafkasya arazisinin sunduğu tarım imkânları da bir dereceye kadar Müslümanları buraya çeken sebepler arasında gösterilebilmektedir. Hepsinden önemlisi Müslümanların Doğu Roma'yla olan sınırlarının güvenliğini sağlamak ve bölgeden gelebilecek akınları durdurmak, tüm bunları yaparken de bölgenin İslamlaşmasını sağlamak en önemli öncelikler arasındaydı. Tüm bu gelişmeler Müslümanların bölge halkına karşı tutumunu, yapılan anlaşmaları, alınacak vergilerin miktarlarını ve askeri temasları etkileyen unsurlardı. Bu çalışmanın amacı Müslümanların bu politikalarına yön veren etkenleri kaynaklar doğrultusunda ortaya çıkarmaktır.
\end{abstract}

Anahtar Kelimeler: Azerbaycan, Ermeniye, Emeviler, Doğu Roma

\section{From the first Muslim Domination Abbasids Affecting Internal and External Progresses to South Caucasian Policy of Muslims}

\section{Abstract}

Azerbaijan, Armenia and Arran geographies, which are called South Caucasus, immediately afterwards the conquest of the Sassanian lands, entered the activity area of Muslim conquerors at the time of Hz.Omer. The first reason of that why muslims find here attractive is that East Roman's military activities attempts against Muslims in addition to harsh policies that

\footnotetext{
* Yrd. Doç. Dr., Artvin Çoruh Üniversitesi, Fen-Edebiyat Fakültesi, Tarih Bölümü, bayramarifkose@gmail.com. (ORCID ID: 0000-0002-9900-9835).
}

(Makale Gönderim Tarihi: 17.05.2017, Makale Kabul Tarihi: 23.08.2017). 
apply to Caucasian people by East Roman. During wars against Sassanids, locals especially Armenians give support to Sassanid armies with crowd forces. This reason also make Muslims find here attractive. The economic resources provided by the Caucasus land attract Muslims to some extent to stay here. It was important for Muslims that maintain boundaries against East Roman and also prevent attack possibilities from the surroundings. Through it all the most important thing was ensure the area convert to Islam. All these progresses influence Muslims attitude towards locals and also influence agreements, the amount of taxes to taken and military contacts. The aim of this study is to reveal the factors according to sources that give direction to these policies of Muslims.

Keywords: Azerbaijan, Armenia, Umayyad, Eastern Roma

\section{Giriş}

Çalışmamıza konu olan Güney Kafkasya'nın sınırları bugün Gürcistan coğrafyasından başlayıp Ermenistan'ı ve Azerbaycan'ı içine alıp İran'ın iç kesimlerine kadar uzanarak İran'ın kuzey kesimlerini de kapsar. Eski çağlardan beri çeşitli milletlerin hâkimiyet sahasında olan bölgenin İslam tarihi açısından önemi İslamiyet'in hemen başlarından itibaren artarak devam etmiştir. Asya'dan Avrupa'ya ulaşan ticaret yollarının üzerinde yer alması ekonomik anlamda bölgede siyasi rekabeti de arttırmıştır. Ayrıca bölgedeki siyasi oluşumların zayıflığı dönemin büyük güçlerinin bölgeye müdahalesini kolaylaştırmıştır. Daha önce Doğu Roma Devleti'yle Sâsânîler arasındaki çekişmelere sahne olan bölge Müslümanların Sâsânîleri ortadan kaldırmasından sonra Müslümanlar, Doğu Roma ve Hazarlar arasındaki mücadelelerin temel sebepleri arasında yerini almıştı. ${ }^{1}$

Güney Kafkasya'nın en önemli kısmını oluşturan Azerbaycan M.Ö. 7. yüzyıl başlarında Medlerin hâkimiyetine girmişti. M.Ö. 6. yüzyılın ikinci yarısında Pers hâkimiyetine giren Azerbaycan'da Selefki hükümdarına bağlı olan Atropatene Krallığı M.Ö. 3. yüzyılın sonuna doğru devlet halini aldı. Romalıların hâkimiyetinden sonra zaman zaman Partlarla Romalılar arasında el değiştirdi. Daha sonra Sâsânîlerin eline geçen bölge 624 yılında Herakleios tarafından Doğu Roma

\footnotetext{
${ }^{1}$ Aliyev Salih Muhammedoğlu, “Kafkasya (Tarih)”, DiA, c. 24, 2001, s. 158.
}

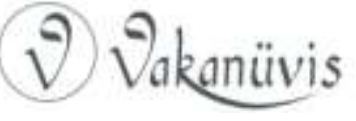


sınırlarına dâhil edildi. ${ }^{2}$ Gürcistan'da ise İskender'in (M.Ö. 356-323) seferlerinden sonra Kartloslu Parnavaz (M.Ö. 302-237) Gürcistan'ın ilk Kartlı kralı olmuş ve bölgede Kartlosluların hâkimiyeti başlamıştır. Ancak daha sonra bölge Ardeşir'in oğlu Mirian (M.S. 265-342) zamanında Sâsânî hâkimiyetine girmişti. ${ }^{3}$ Ermeniye ise Medlerin (M.Ö. 612-549) hâkimiyetinden sonra Perslerin (M.Ö. 549-330) 13. Satraplığını oluşturdu. M.Ö. 331 yılında İskender Asya seferiyle birlikte burayı da hâkimiyetine aldı. Daha sonraki Sâsânî hâkimiyeti ise Doğu Roma'yla Sâsânîler arasında bölgeye hâkim olma mücadelelerinin en yoğun yaşandığı dönemlerden biri oldu. ${ }^{4}$

Bölgenin Müslüman hâkimiyetine girmesiyle birlikte idari, iktisadi, zirai ve kültürel alanlar başta olmak üzere pek çok alanda değişiklikler meydana geldi. Ticaret yollarının oluşmasıyla birlikte yeni yerleşim yerleri de meydana gelmişti. İslam fetihleri sırasında gerek savunma amaçlı gerekse imar amaçlı pek çok kale ve şehrin imar edildiği

2 Ziya Musa Büniyatov, Azerbaycan VII-IX Eserlerde, Bakü 2007, s. 49; Büniyatov, "Azerbaycan" DiA, c. 4, 1991, s. 318-319.

${ }^{3}$ Gürcistan Tarihi (Eski Çağlardan 1212 Yılına Kadar), (Gürcüceden Çev: Marie Féliceté Brosset), (Çev: Hrand D. Andreasyan), (Notlar ve Yayına Hazırlayan: Erdoğan Merçil), TTK, Ankara 2003, s. 20, 61; Kartlis Tskhovreba (History of Georgia), (Translated: Dmitri Gamq'relidze, Medea Abashidze, Arrian Chant'uria), (Edit: Roin Met'reveli, Stephen Jones), Georgian National Academy of Sciences, Artanuji Publishing, Tbilisi 2014, s. 22, 41-42; Ömer Subaşı, "Arap Akınlarına Kadar Artvin ve Çevresi”, A. Ü. Türkiyat Araştırmaları Enstitüsü Dergisi, Sa. 49, Erzurum 2013, s. 325.

${ }^{4}$ René Grousset, Başlangıçtan 1071'e Ermenilerin Tarihi, (Çev: Sosi Dolanoğlu), Aras Yayıncılık, İstanbul 2006, s. 72, 74, 77, 110-113, 158-176; Robert H. Hewsen, The Geography of Ananias of Širak (AŠXARHAC'OYC'), Wiesbaden 1992, s. 147; Sâsânîlerle Roma Devleti arasındaki mücadelelerde üstünlük sağlayamayan taraflar çareyi bölgeyi bölüp aralarında paylaşmakta bulmuşlardı. Üstünlüğü zaman zaman kaybeden Romalılar daha önce ele geçirdikleri Arzanene, Moxoene, Zabdicene, Rehimene ve Corduene gibi satraplıklardan çekilmek zorunda kalmışlardı. 387 tarihinde yapılıp 591 yılına kadar pek fazla değişikliğe uğramadan yürürlükte kalan Akilisene (Ekeleats) anlaşmasına göre Ermenistan doğu ve batı olarak ikiye ayrılmıştı. Bu yeni değişikliğe göre Batman Suyu, Pers Ermenistan'ı ile Roma Ermenistan'ı arasında sınır kabul edildi. Detaylı bilgi için bkz. A. H. M. Jones, The Cities of the Eastern Roman Provinces, Oxford 1971, s. 223-224; Mehmet Tezcan, "İran Armeniası (Pers-Armenia), Tarihte Türkler ve Ermeniler (ilkçağ-Ortaçağ), c. I, TTK, Ankara 2014, s. 164; VI. Yüzyılda da Doğu Roma ile Sâsânîler arasında bölünmüş olan Kafkasya'da Armenia'nın Persarmenia olarak da bilinen büyük bölümü ve Gürcistan'ın aşağı kısımları 526-532 savaşlarından sonra Sâsânî hâkimiyetindeydi. Armenia'nın geri kalan kısmı ile Gürcistan'ın yukarı kısımları ise Doğu Roma hâkimiyetinde kaldı. Bkz. Subaşı, "Artvin ve Çevresi", s. 328.

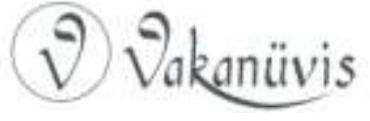


görülmektedir. Genel itibariyle tüm bu bilgilere ayrıntılı olarak değinen İslam coğrafyacıları bu verimli coğrafyayı Azerbaycan, Ermeniye ve Arran başlığı altında İklim-i Rihâb veya İklimü'l-Hâmis (Beşinci Bölge) olarak ele almıştır. Onların belirttiği sınırlara göre, doğuda Hazar Denizi'nin batısına, batıda Ermeniye'ye, kuzeyde Kafkas dağlarına, güneyde ise Irak ve Cezîre'nin bir kısmına ulaşan bu geniş bölge, Erdebil, Meraga, Urmiye, Tebriz, Mugan, Debîl (Dvin), Tiflis, Berze'a, Şervân, Bâbü'l-Ebvâb (Derbent) ve Bakü gibi önemli merkezleri içine almaktaydı. ${ }^{5}$

\section{Illk Müslüman Akınları ve Anlaşmalar}

Müslümanların Güney Kafkasya'ya olan ilgisi aslında bölgeyle alakalı olmaktan ziyade özellikle Doğu Roma İmparatoru Herakleios (610641)'un ve varislerinin Ermenilere olan yakınlığıyla alakalıydı. Ermeni soyundan geldiği öne sürülen ve gençlik yıllarını Ermenistan'da geçiren Herakleios ordusunu büyük oranda Ermenilerden oluşturmuştu. Onun Sâsânîlerle olan savaşında ordusunda görev yapan Hıristiyan Araplara alternatif olarak Ermenilerden asker toplaması buranın onun için ne kadar önemli olduğunu ortaya koymuştu. Bu ordu yaklaşık 80 bin kişiden oluşmaktaydı. Müslümanlar açısından ise Doğu Roma askeri gücünü bu denli öneme sahip olan Ermenilerden mahrum bırakmak ancak bölgeye hâkim olmakla veya Ermenilere Herakleios'tan daha yakın davranmakla mümkün olacaktı. Daha ilk dönemlerden itibaren iki büyük gücün birbirlerine en yakın oldukları noktada Ermeniler her iki taraf için de büyük bir öneme sahip oldu. ${ }^{6}$ Ermeniler de ellerine geçen bu avantajı iyi kullandılar ve krallıklarını her iki tarafa da dayandırmayı inmal etmediler. Bununla birlikte sadece Herakleios'un değil aynı

\footnotetext{
${ }^{5}$ Güney Kafkasya'nın tarihsel coğrafyası için bkz. Ebu İshâk ibrâhim b. Muhammed elİstahrî el-Fârisî, el-Mesâlik ve'l-Memâlik, (Tahkik: Muhammed Câbir Abdulâl el-Hînî), 1961, s. 108-114; Ebü'l-Kâsım İbn Havkal en-Nasibî, Sûretü'l-arz, (Neşr: M. J. De Goeje), (Bibliotheca Geographorum Arabicorum c. II), Leyden 1967, s. 301-355; Şemsüddîn Muhammed b. Ahmed b. Ebî Bekr el-Bennâ el-Makdisî eş-Şâmî el-Beşşârî, Ahsenü'ttekâsîm fî ma'rifeti'l-ekâlîm, (Neşr: M. J. De Goeje), Brill 1877, s. 373-384; Hudûdü'lÂlem Mine'l-Meşrik Ile'l-Magrib, (Neşr: Vladimir Minorsky), (Çev: Abdullah Duman, Murat Ağarı), İstanbul 2008, s. 101-104.

${ }^{6}$ Alexander A. Vasiliev, Bizans imparatorluğu Tarihi, (Çev: Tevabil Alkaç), İstanbul 2016, s. 229; Walter E. Kaegi, Bizans ve Illk İlam Fetihleri, (Çev: Mehmet Özay), İstanbul 2000, s. 239, 253, 279; John Julius Norwich, Bizans Erken Dönem (MS 323802), c. 1, (Çev: Hamide Koyukan), İstanbul 2013, s. 249.
}

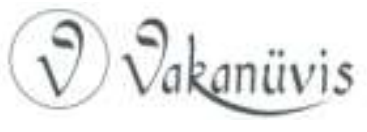


zamanda Sâsânîlerin de ordusunda görev yapıyor olmaları Ermenileri bölgede var olan üç büyük güç için de önemli yapmıştı. Ancak bu durum onlara her zaman avantaj sağlamadı.

Ermenilere oldukça yakın davranan Herakleios çeşitli savaşlarda çok sayıda Ermeni askeri birliğine ordusunda yer vermeyi inmal etmedi. Yermuk savaşında ordusunda 12 bin Ermeni askerin görev yaptığı ileri sürülmektedir. ${ }^{7}$ Durum bununla da sınırlı değildi. Mezopotamya'da Müslümanlara karşı girişilen mücadelede Ermeni askerleri yoğun bir şekilde Doğu Roma saflarında yer alarak Müslümanların karşısında olduklarını ortaya koymuştu. Diğer taraftan ilk İslam fethi sırasında Ermenilerin savaşçı bir millet olmalarına rağmen bölgenin oldukça savunmasız kaldığı görülmektedir. Doğu Roma'nın Mezopotamya hâkimiyeti için Müslümanlarla girdiği mücadelede Rubil el-Ermeni adlı komutanın yanı sıra emrindeki 4 bin askerle savaşa katılan Yuryak elErmeni adlı Ermeni komutanı Doğu Roma'nın Ermenilere yakınlık göstermesinin sebeplerini ortaya koyduğu gibi Ermenilerin askeri varlığının nerelerde tükendiğini de açıklamaktadır. Ermeni askerlerin Doğu Roma'ya desteği bununla da sınırlı kalmadı. Harran yöneticisi Revdes'in oğlu Arcuk el-Ermeni de Müslümanlara karşı başarısız girişimlerde bulunmuştu. Diğer bir Ermeni komutan ise Resulayn'ın Müslümanlara karşı savunulmasında Şehriyad'ın yardım isteğine kızı Tarbun'u 4 bin askerle birlikte yardıma gönderen Ahlat yöneticisiydi. ${ }^{8}$ Bu sebeple İyâd b. Ganem fethettiği yerlerin güvenliği için olası Ermeni saldırılarına karşı tedbir almak zorundaydı. Ayrıca Herakleios'un dini dayatmaları Ermeni feodaller arasındaki ihtilafları ve çatışmaları arttırarak bölgede karışıklıklara neden olmuştu. Bu karmaşık durum yeni fethedilen bölgelerin güvenliği için tehdit oluşturuyordu. Hem Sâsânîlerin bölgede kaybolan otoritesi hem de Doğu Roma'nın yanlış ve zayıf politikaları Ermeni yöneticileri bağımsızlık için az da olsa umutlandırmıştı. Müslüman hâkimiyetinden hemen önce Doğu Roma'nın Ermenistan'daki Ermeni askeri birliği yaklaşık 15 bin ile 30 bin arasında askerden oluşmaktaydı. Illk Müslüman fetihlerinin hemen öncesinde Suriye'de pek çok Ermeni askeri hayatını kaybetmiş bununla

\footnotetext{
${ }^{7}$ Kaegi, a.g.e., s. 283.

${ }^{8}$ Ebû Abdillâh Muhammed b. Ömer b. Vâkıd el-Vâkıdî el-Eslemî el-Medenî, Fütûhu'şŞâm, c. 2, (Neşr: Abdüllatif Abdurrahman), Beyrut 1997, s. 97, 104, 118, 121.
}

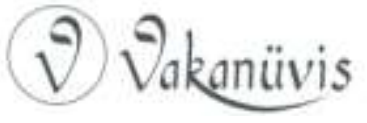


birlikte Doğu Roma'nın Ermenistan'ı savunmak için her hangi bir adımı olmamıştı. ${ }^{9}$

Müslümanların Güney Kafkasya'ya ilk akınlarına yönelik rivayetlerden anlaşıldığına göre Muğire b. Şu'be, Kûfe'ye gelerek Nihavend dolaylarında bulunan Huzeyfe b. el-Yeman'ın bölgeye vali atandığına dair mektubu kendisine ulaştırmış ve Müslümanların bölgeyle ilk kapsamlı ilişkilerini bu şekilde başlatmıştı. Mektubun kendisine ulaşmasıyla Azerbaycan valiliğine başlayan Huzeyfe H. 18 (639) yılında Azerbaycan'ın merkezi ve Merzuban'ın ikamet yeri olan Erdebil'e gelerek şiddetli çarpışmalara girdi. Kendisine vergi vermekle yükümlü olan çevre halkını da desteğe çağırmış olmasına rağmen Müslüman birlikler karşısında yenilen Merzuban, Azerbaycan halkı adına 8 miskal ağırlığında 800 bin dirhem vergi vermek şartıyla, bölge halkının canını ve hürriyetini kurtarmıştı. Ayrıca anlaşma metnine ateşgede mabetlerine dokunulmaması ve bayram törenlerini serbestçe yerine getirmeleri şartlarını da ekleterek halkının dini özgürlügünü temin etti. Bu fethin tarihiyle ilgili Belâzurî'de H. 18 (639) olduğuna ilişkin kayda rastlanmasa da Taberî ve íbnü'l-Esîr bu tarihte buranın fethine dair bir rivayetin olduğunu belirtir. Ayrıca Belâzurî'deki bir rivayet de Huzeyfe'nin Azerbaycan halkıyla 100 bin dirhem karşılığında sulh yaptığı yönündedir. ${ }^{10} \mathrm{Bu}$ vergi miktarları ve anlaşma şartları Müslümanların bölgede uygulamış olduğu ilk vergi sistemi olması nedeniyle mühimdir. Bununla birlikte anlaşmanın diğer maddeleri bundan sonra bölgede uygulanacak olan hoşgörü politikasının ilk modelini oluşturmuştu. Müslümanlar buraya hâkim olmaktan ziyade halkı kendilerine yakınlaştırmayı daha çok önemsiyorlardı.

\footnotetext{
${ }^{9}$ Kaegi, a.g.e., s. 285-286.

10 Ahmed b. Yahyâ el-Belâzurî, Fütûhu'l Büldân (Ülkelerin Fetihleri), (Çev: Mustafa Fayda), Siyer Yayınları, İstanbul 2013, s. 372-373; Ebû Ca'fer Muhammed b. Cerîr etTaberî, Târîhu'r-Rusûl ve'l-Mulûk (Taberî Tarihi), c. 4, (Tahkik: Muhammed Ebu'l Fazl İbrahim), Beyrut 1967, s. 146; Ebu'I-Fida İbnü'l-Esîr, Ali b. Muhammed b. Abdilkerîm elCezerî eş-Şeybânî, el-Kâmil fi't-Târîh, (İslâm Tarihi), c. 2, (Tecüme Heyeti: Ahmet Ağırakça, Beşir Eryarsoy, Zülfikar Tüccar, Abdülkerim Özaydın, Yunus Apaydın, Abdullah Köşe), Ocak Yayıncılık, İstanbul 2016, s. 517; Şihâbiddîn Ebi Abdillâh Yâkût b. Abdillâh el-Hamevî er-Rûmî el-Bağdâdî, Mu'cemü'l-Büldân, c. 1, Beyrut 1977, s. 129; Ebü'l-Fidâ' İmâdüddîn İsmâîl b. Şihâbiddîn Ömer b. Kesîr b. Dav' b. Kesîr el-Kaysî elKureşî el-Busrâvî ed-Dımaşkî eş-Şâfiî (íbnü'l-Kesîr), el-Bidâye ve'n-nihâye, c. 7, (Çev: Mehmet Keskin), Çağrı Yayınları, İstanbul 1985, s. 210-214.
}

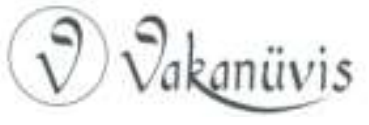


Müslümanların Ermenilere karşı ilk dönemlerde uyguladığı bu olumlu politika daha sonraki dönemler içinde model olmuştu. Hatta fethedilen diğer bölgelere nispetle bu bölgeye uygulanan politika ve Ermenilere verilen ayrıcalıklar daha sonraki dönem kaynakların da dikkatini çekmişti. Müslümanların Ermenilere bakış açısı kaynaklara göre oldukça olumluydu. İbn Havkal'ın H. 325 (937) senesine kadar Bağdat'ta Ermeni kölenin satılmamış olmasına dikkat çekmesi ${ }^{11}$, dönemin olumlu izlenimlerini doğrulamakla birlikte daha sonraki dönemlerde yaşanan siyasi gelişmelerin Müslümanları bölge politikalarını değiştirmeye zorladığını da kanıtlamaktadır.

Daha ilk Halife Ebu Bekir'den itibaren halifelerin fatihlerine ilettiği tavsiyelerde fethedilen bölge halkına iyi davranılması hususunun üzerinde duruluyor ${ }^{12}$ ve bunun yanında onların himayesi için belli miktarda vergi alınıyordu. Bu anlamda valilerin kişisel uygulamalarının getirdiği problemler de yaşanabilmekteydi. Ancak genel anlamda İslamiyet'in bölgede yayılması ne çok sert ne de çok yumuşak olmuştu. Bununla birlikte bazı araştırmacılar Arran'da islamiyet'in Azerbaycan'dan daha hızlı yayıldığını ileri sürmekte ve bunun nedenini buradaki varlıklı kesimin mevkilerini korumak için bu yola başvurduklarını belirtmektedir. Ancak Arran'da çoğunlukta dini hoşgörüsü ön planda olan Türklerin İslamiyet'i benimsemiş olması bu görüşü zayıflatmaktadır. ${ }^{13}$ Diğer taraftan Doğu Roma ve Sâsânîlerin dönemindeki vergi miktarlarıyla yapılan karşılaştırmada Müslümanların bazı dönemlerde çoğunu hediyelerin oluşturduğu az miktarda vergi koyması da bölge halkının İslamiyet'e geçişini kolaylaştırdı. Bununla birlikte Hz. Ömer'in İslam dinini kabul etmiş olan köylüye belli süre hazineden maddi destek sağlaması daha önce görülmemiş uygulamalar

\footnotetext{
${ }^{11}$ ibn Havkal, a.g.e., s. 343; 1394-1427 tarihleri arasında Müslüman memleketlerinde seyahat eden Johannes Schiltberger, Hz. Muhammed'in Ermeniler hariç, Müslümanlara karşı gelenlerle savaşmayı emrettiğini belirtmiştir. Yine Schiltberger'in notlarına göre Ermenilerin kendi aralarında serbest olmaları, eğer Müslüman idaresindeyseler onlardan ayda iki pfennig (metelik)'den fazla haraç alınmaması da emredilmişti. Johannes Schiltberger, Türkler ve Tatarlar Arasında (1394-1427), (Çev: Turgut Akpınar), ìstanbul 1997, s. 163.

${ }^{12}$ ibnü'l-Esîr, a.g.e., c. 2, s. 287, 523.

${ }^{13}$ İsmail Mehmetov, Türk Kafkası'nda Siyasi ve Etnik Yapı, Eski Çağlardan Günümüze Azerbaycan Tarihi, (Eklemeler, Notlandırma ve Düzenlemelerle Türkçe Yayına Hazırlayanlar: Ekber N. Necef, Şamil Necefov), Ötüken Neşriyat, İstanbul 2009, s. 171.
}

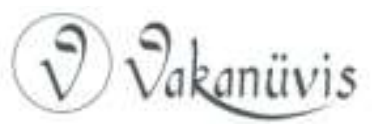


olarak halkın teveccühünü kazandı. ${ }^{14}$ Özellikle Müslümanlarla Ermeniler arasında en olumlu münasebetlerin kurulduğu Muaviye (4160/661-680) döneminde ${ }^{15}$ bölgede dikkat çeken bazı köklü reformların Müslümanların bölgedeki önceliklerinin anlaşıması açısından mühimdir. Birinci önceliği bölgenin İslamlaştırılması olan Müslümanlar bu anlamda bölgede siyasi ve ekonomik istikrarı sağlamak için büyük çaba sarf etmişlerdi. Rüşvet ve idari bozuklukların tespiti için kurulan Darü'I-İstihraç'ın faaliyet raporu Halife'nin bölgede görev yapan tüm memurları değiştirmesine neden oldu. Raporları inceleyen Halife toplanılan para ile hazineye aktarılan paranın arasındaki tutarsızlığı affetmemiş ve bu hususta taviz vermeyeceğini belirtmişti. Bu uygulama önce eyalet yöneticilerinin sonra onları takiben halkın İslamiyet'i tercih etmesinde büyük öneme sahiptir. ${ }^{16}$

Azerbaycan'a yönelik ilk fetihlerin tarihi hakkında kaynaklarda yer alan farklı rivayetlere rağmen kesin fetih hareketinin Nihavent Savaşı'nı takiben H. 22 (642-643) yıllarında başladığı kabul edilmektedir. ${ }^{17} \mathrm{Bu}$ tarih, öncesinde yaşanan olaylar ve Müslümanların bu olaylardan etkilenmesi buraya yönelik fetihlerin sebebini de aydınlatması açısından önemlidir. Öyle ki Müslümanların bu bölgelere fethe karar vermesinde en önemli etken Sâsânîlerle olan savaşlarında bölge halkının Müslümanlara karşı tavırları ve karşıt saflarda yer almaları mühim bir etkiye sahiptir. Dolayısıyla bölge halkının Müslüman karşıtı ittifaklarda yer alması Müslümanları bu bölgeyi fethedip en azından daha sonra girişilecek muhtemel ittifakları da böylece önceden bitime gayretine sevk etti. Müslümanlar kendisine karşı tehlikeli bulduğu bu ittifakların ilkiyle H. 15 (637) yılında karşılaştı. Henüz Kadisiye Savaşı'nın yapıldığı sıralarda İran hâkimiyetindeki Güney Kafkasya'dan Rüstem'in ordusuna bir hayli katılım olmuş ve

\footnotetext{
${ }^{14}$ Büniyatov, a.g.e., s. 114-115.

${ }^{15}$ Ali İpek, Ortaçağ Müslüman Idarelerde Ermeniler-Makaleler-, Atatürk Üniversitesi Yayınları, Erzurum 2015, s. 13.

${ }^{16}$ Büniyatov, a.g.e., s. 153.

${ }^{17}$ Taberî, a.g.e., c. 4, s. 146; Ebü'l-Abbâs Ahmed b. Ebî Ya'kūb İshâk b. Ca'fer b. Vehb b. Vâzıh el-Ya'kūbî, Târîhu'l-Ya'kūbî, c. 2, (Tahkik: Abdülemir Mehna), Beyrut 2010, s. 49; İbnü'l-Esîr, a.g.e., c. 2, s. 517; Belâzurî'de yer alan başka bir rivayete göre H. 20 yılında Muğire burayı fethetmiş ancak buranın halkının kâfir olması nedeniyle Eş'as b. Kays elKindî buranın üzerine tekrar yürüyerek Muğire'nin yapmış olduğu anlaşmayı tekrar yürürlüğe koymuştu. Belâzurî, a.g.e., s. 372-373.
}

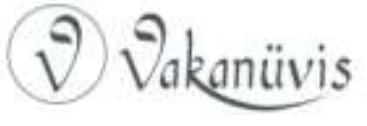


ordu 80 bin civarına yükselmişti. İranlılara yardım eden Muşeğ Mamigonyan idaresindeki sadece Ermeni birliği 30 bin civarındaydı. Yine Sünik prensi Grigor'un emrinde de İranlılara yardıma gelmiş bin kadar asker vardı. ${ }^{18}$ Bununla birlikte íbnü'l-Esîr H. 16 (637-638) yılı olayları arasında Celûlâ vakasından bahsederken Farslılarla birlikte kaçan grup arasında Azerbaycanlı Bâb halkının da yer aldığını belirtir. ${ }^{19}$ Ancak Ermenilerin Sâsânîlere yardımı kendilerine pahalıya mal oldu. Bu yenilgide kaçıp ülkelerine dönen İran birlikleri kadar şanslı olmayan Muşeğ ve iki kız kardeşi ayrıca Grigor ve bir oğlu da ölenler arasında yerini almıştı. İran birliklerinin bir kısmı ise Azerbaycan'da toplanıp hazinelerle kaçmaya çalışsalar da Müslümanlar bu hazineleri de ele geçirip ülkelerine dönmüşlerdi. ${ }^{20}$ Nihavent Savaşı'yla birlikte bölgede Sâsânî idaresinin yıkılmasıyla da iş bitmiş değildi. Güney Kafkasya'nın feodal yöneticileri bu kez Müslümanlara karşı zaman zaman Doğu Roma'yla ittifak halinde oldular.

Müslümanların Ermeniye bölgesinde takip edecekleri politikalar Azerbaycan'daki gibi Nihavent Savaşı'nı takiben daha belirginleşti. Genellikle az bir vergiyle itaatin sağlanmasına yönelik politikalar uygulanırken Müslüman karşıtı ittifaklardan vazgeçirme meselesi göz önünde bulundurulmuştu. Müslümanlar çok vergi ve hürriyet kısıtlaması gibi ağır şartlar dayatıp bölge halkını kendilerinden uzaklaştırmak veya iyice serbest bırakıp otoritelerini hafife aldırmak istemiyorlardı. Aradaki dengenin korunması için bölge valilerine devamlı telkinlerde bulunuluyordu. Müslümanlar H. 16 (637) yılından itibaren akınlara başladıkları Ermeniye'ye İslam kaynaklarının verdiği bilgilere göre Hz. Ömer döneminde H. 18 (639) yılında İyâd b. Ganem gönderilmişti. Onun Habib b. Mesleme'nin gelişinden önce bölgede olduğunu ve burada bir takım anlaşmalar yaptığını Belâzurî'deki bir kayıt doğrulamaktadır. Zira Habib b. Mesleme Kâlikalâ'dan sonra Ermeniye'deki ilerleyişine Hılât'tan devam etmiş, buranın patriği kendisine daha önce İyâd b. Ganem'den almış olduğu emanı gösterince

\footnotetext{
${ }^{18}$ Konuyla alakalı detaylı bilgi için bkz. Movses Dasxurants'i's, History of the Aghuans, (Translated: Robert Bedrosian), s. 80-84; Sebeos, History, (Translated: Robert Bedrosian), Sources of the Armenian Tradition, New York 1985, s. 107; Mehmetov, a.g.e., s. 167; ipek, a.g.e., s. 11.

19 ibnü'l-Esîr, a.g.e., c. 2, s. 454.

${ }^{20}$ Sebeos, a.g.e., s. 107.
}

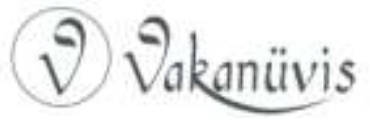


Habib b. Mesleme' de bu emana uymuştu. İbnü'l Esîr bu olayları H. 25 (645-646) yılı olayları içerisinde ele almaktadır. Ermeni kaynakları ise bu ilk akının H. 18 (639) yılında gerçekleştiğini ve Müslümanların ilk olarak Koğtan ve Nahçıvan'a geldiklerini belirtir. Bu akının amacı da Teodoros Rshtunik komutasındaki Ermeni birlikleri ve Procopios komutasındaki Doğu Roma güçlerinin oluşturduğu ittifakı bozmaktı. Bu ilerleyiş onların konakladığı Kogovit'e kadar devam etti. ${ }^{21}$ Müslümanlar Doğu Roma hâkimiyetindeki Mezopotamya'yı ele geçirince burayı tehdit edecek tek gücün Ermeniler olduğunun farkındaydılar. Bununla birlikte Ermenilerin savunma zaafları görülmüş olmasına rağmen Müslümanların bu akınlarını fetihle sonuçlandırmaması manidardır. Ama yine de Ermenistan'dan gelebilecek tehlikeye karşın gerek fetih yoluyla gerekse anlaşma yoluyla Ermenilerin askeri gücünü ortadan kaldırmak ya da kontrol altına almak İslam Devleti'nin ilk öncelikleri arasında yerini aldı. ${ }^{22}$ Çünkü daha önceki fetihler, düşman saflarında çarpışan Ermeni askeri gücünün oluşturduğu tehlikeyi tecrübe etmeye yetmişti.

Müslümanların bölgeye gelişleri ve çeşitli akınlarıyla alakalı olarak kaynaklar arasındaki tutarsızlığın sebebi kaynakların yanlışlığıyla değil, Müslümanların bölgede yavaş ilerleyişiyle izah edilebilmektedir. Aslında bu tutarsızlık bize Müslümanların bölge politikalarına dair bazı ipuçları da vermektedir. Anlaşıldığına göre Müslümanlar kendileriyle henüz tanışmış olan bu coğrafyada ele geçirdikleri yerlerde uyguladıkları politikalar ve yürürlüğe koydukları anlaşmalar kısa sürede yerel ahali tarafından bozulmakta ve Müslümanların tekrar sefere

\footnotetext{
${ }^{21}$ Belâzurî, a.g.e., s. 230; i̇bnü'l-Esîr, a.g.e., c. 2, s. 574; Ghewond, Ghewond's History, (Translated: Robert Bedrosian), Sources of the Armenian Tradition, Long Branch, N. J., 2006, s. 7; Taberî de H. 17 (638-639) yılı olaylarını anlatırken Müslümanların Ermeniye'ye akınlar yaptıklarını belirtir. Taberî, a.g.e., c. 4, s. 53; Ermeniye'nin önemli kalesi olan Dvin'e ilk hücumun, Mezopotamya'nın Doğu Roma elindeki kısmının alınmasından hemen sonra Ekim 640 yılında gerçekleştiği belirtilir. İkinci saldırı ise Suriye ve Mezopotamya'nın kesin olarak ele geçirilmesinin hemen akabinde 642 yılında gerçekleşti. Bkz. Georg Ostrogorsky, Bizans Devleti Tarihi, (Çev: Fikret Işıltan), TTK, Ankara 2006, s. 103, 108; Ya'kūbî'de Habib b. Mesleme el-Fihri'nin H. 22 (642643)'lerde Ermeniye'ye ilerlediği kaydedilir. Ya'kūbî, a.g.e., c. 2, s. 50; Ayrıca bkz. Samouel D’Ani, Tables Chronologiques, (Neşr: Marie Félicité Brosset), Collection D'Historiens Armeniens, S-Petersbourg, 1876, s. 401.

${ }^{22}$ Kaegi, a.g.e., s. 290.
}

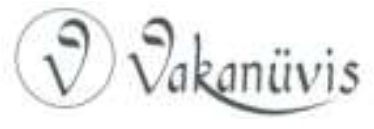


çıkmasına neden olmaktaydı. Ele geçirdikleri yerlerden hemen ayrılmayan askerler bir süre başta vergi olmak üzere anlaşmadaki çeşitli konuları halka kabul ettirmek için çaba sarf ediyorlardı. Böylece anlaşma maddelerinin ihlali bir sonraki seferin de sebebi oluyordu. ${ }^{23}$ Müslümanların ilerleyişini yavaşlatan tek etken bölge halkının anlaşmaları benimsemede çıkardığı sorunlar değildi. Şiddetli iklim şartları ve engebeli arazi şartları da büyük problemlere neden olmuştu. Bu şartlar göz önünde bulundurulmadan yapılan birkaç strateji hatası yüzünden Müslümanlar doğa şartları karşısında pek çok kayıp vermişlerdi. ${ }^{24}$ Tüm bu sebepler neticesinde Müslümanlar akın yaptıkları bölgelere kısa süre içerisinde tekrar gelmek zorunda kalıyorlardı. Bir nevi ilk gelişleri bölgeyi ve halkını tanıma imkânı veriyor daha sonraki gelişleri ise daha kapsamlı ve kalıcı oluyordu. Kaynaklar ise kısa sürede peş peşe gerçekleşen bu seferlerin ya ilkinin tarihini kaydediyor ya da ikinci veya üçüncü seferin tarihini kaydetmeyi uygun görüyordu. Bu da kaynakların tutarsızlığını açıklamaktadır.

Diğer taraftan Ermeni nakhararlarla Doğu Roma arasında devam eden ittifakın yanı sıra Doğu Roma'nın her fırsatta bölgeye birlik sevk ediyor olması nedeniyle Hz. Ömer H. 21 (641-642) yılında fetih için bazı yerlere adamlarını gönderdiği sırada Utbe b. Ferkâd'la birlikte Bukeyl b. Abdullah'ı da Azerbaycan'a gönderme ihtiyacı hissetmişti. ${ }^{25}$ H. 22 (642-643) yılında Numan b. Mukarrin Hemedan'ın fethi için orada bulunduğu sırada Deylemiler Rey ve Azerbaycan halkına mektuplar gönderip onları kendi birliklerinin yanında savaşa davet ettiler. Davete uyan Azerbaycan halkından Rüstem'in kardeşi İsfendiyar ordusuyla birlikte Müslümanların karşısında yer almış ancak bu müttefik ordu Müslümanlar karşısında başarı elde edememişti. ${ }^{26}$ Kendisine yardımcı olarak gönderilen Simâk b. Hareşe el-Ensâri komutasındaki birlikler henüz bölgeye varmadan, Bukeyl burada yapmış olduğu ilk çarpışmada İsfendiyar'ı mağlup ederek esir aldı. İsfendiyar kendisine, Azerbaycan halkının dağlık alanlarda karargâh kurduğunu ve sulh edilmezse ona

\footnotetext{
${ }^{23}$ Nailə Vəlixanlı, Arab Hilafeti ve Azerbaycan, Bakü 1993, s. 15.

${ }^{24}$ Robert H. Hewsen, Armenia A Historical Atlas, The University of Chicago Press, London 2001, s. 105.

${ }^{25}$ Taberî, a.g.e., c. 4, s. 138; ìbnü'l-Esîr, a.g.e., c. 2, s. 513.

${ }^{26}$ Taberî, a.g.e., c. 4, s. 148; İbnü'l-Esîr, a.g.e., c. 2, s. 517-518; ỉbnü'l-Kesîr, a.g.e., c. 7, s. 200-202.
}

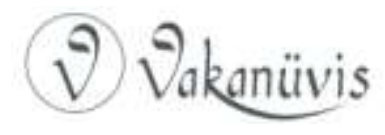


itaat etmeyeceklerini söylemiş ve bu vesile ile Bukeyl'i sulha razı etmişti. Böylece Azerbaycan bir kale hariç sulh yoluyla itaate alınmış oldu. Bundan sonra fethedilmeyen kale Simâk b. Hareşe el-Ensâri'nin bölgeye ulaşmasından sonra büyük oranda ele geçirildi. Bukeyl $\mathrm{Hz}$. Ömer'den Bâbü'l-Ebvâb'a doğru gitmek için izin isteyince Utbe b. Ferkâd Azerbaycan genel valisi tayin edilmişti. Bundan sonra Müslümanlar Bâbü'l-Ebvâb hâkimi Şehriyâr'ın kendiliğinden cizye ödemeyi kabul etmesiyle bu şehre de hâkim olmuşlardı. Şehriyâr yaptığı görüşmede Müslümanların istediklerini yerine getireceğini belirtmekle birlikte cizyenin arttırımamasını talep etmişti. Utbe $b$. Ferkâd kendisine saldıran Behrâm b. Ferruhzâd'ı mağlubiyete uğratmasından sonra hala esir tutulan İsfendiyar sulhun şimdi gerçekleştiğini ve savaş fitnesinin bittiğini belirtmiş böylelikle Azerbaycan tümüyle Müslüman hâkimiyetine girmişti. Buradan ele geçirilen ganimetin beşte biri savaş hukukuna göre merkezdeki hazineye aktarılmak üzere Medine'ye gönderildi. ${ }^{27}$

Diğer taraftan bölgede boşalan Sâsânî otoritesini doldurmaya yönelik Müslümanlarla Doğu Roma arasında amansız yarış daha ilk etapta kendini göstermeye başlamıştı. Müslümanlar haliyle yıkmış oldukları Sâsânîlere ait olan mirası kimseyle paylaşmak niyetinde değillerdi. Bu bakımdan daha önce Sâsânîlere ait olan bölge üstünlüğünün kendilerine geçmesi gerektiğine inanıyorlardı. Bununla birlikte Doğu Roma'da Müslümanlardan farklı düşünmüyor onlar da bölge üstünlüğünün kendilerine geçmesi gerektiğini savunuyorlardı. Ancak sahadaki uygulamaları Müslümanlarınkinden oldukça farklıydı. Müslümanlar az vergilerle bölge halkını kendilerine yakınlaştırmaya çalışırken Romalılar başta dini baskılarının yanı sıra bölgeyi askeri stratejileri açısından değerlendirmek istiyorlar bu bakımdan halkı çok da önemsemiyorlardı. Bu sıralarda bu politikalara uygun olarak Herakleios tarafından atanmış Ermeni prensi Teodoros Rshtunik ${ }^{28}$

${ }^{27}$ Taberî, a.g.e., c. 4, s. 153-157; ỉbnü'l-Esîr, a.g.e., c. 2, s. 522-523; ỉbnü'l-Kesîr, a.g.e., c. 7, s. 202-203; Huzeyfe'den sonra Utbe b. Ferkad'ın Azerbaycan valisi olduğuna dair ayrıca bkz. Belâzurî, a.g.e., s. 372-373.

${ }^{28}$ Teodoros Rshtunik ilk etapta Sâsânî ve Doğu Roma Ermenistanı'nı birleştirip Müslüman akınlarına karşı direndi. Ancak daha sonra Doğu Roma'yla ihtilafa düşüp Müslümanların yanında yer aldı. George A. Bournoutian, A History of the Armenian People Volume I: Pre-History to 1500 A. D., California 1993, s. 92.

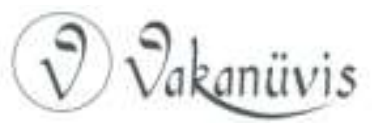


bölgede, Doğu Roma desteğiyle faaliyete devam etmekteydi. Ancak Teodoros Rshtunik'in Müslümanları Eghbark adlı tepede pusuya düşürüp pek çok ganimet ve esir elde etmesi Doğu Roma'nın pek de işine yaramadı. Çünkü hemen akabinde asker sayısındaki ezici üstünlüğe güvenmekle yetinen Doğu Roma Generali Procopios 60 bin askeriyle 10 bin kişilik Müslüman birliğini yenemediği gibi pek çok kayıpla birlikte Müslümanlar tarafından kovalanmaya başladı. Ancak Müslümanların ganimetlerle birlikte ülkelerine dönmeleriyle rahat bir nefes almıştı. ${ }^{29}$ Anlaşıldığına göre çeşitli silahları kullanmada mahir olan Ermeniler Doğu Roma askeri gücünde mühim roller üstlenmeye devam ediyordu. Bununla birlikte hem atlı hem piyade olarak çeşitli kademelerde görev yapmalarına rağmen açık alanda savaşmakta Müslümanlar kadar mahir değillerdi. Ama yine de çölün askerlerine karşı dağıık bölgelerini savunmak onlar için daha basitti. Dahası Doğu Roma yöneticileri tüzel kişilikler vasıtasıyla onların silahlanmasına asla engel çıkarmadı. ${ }^{30}$ Zira onların silahlanması Müslümanların durdurulması için önemli bir hamleydi. Ancak bu riskli girişim Ermenilerin Müslümanların safına geçmeleriyle aksi sonuçlar da doğurabilirdi.

Ghewond'un belirttiğine göre, H. 6 Ekim 642'de Müslümanların Dvin'e saldırdığı sırada hiçbir varlık gösterememiş olmasına rağmen, $\mathrm{H}$. 26 (646-647) yılında Müslümanların bölgeye kanatlı yılan gibi hızlı bir şekilde akınlar düzenlediği esnada da Ermeni birlikler Teodoros Rshtunik tarafından idare ediliyordu. İslam kaynakları Dvin'e girişile alakalı kesin bir tarih vermemekle birlikte íbnü'l Esîr H. 22 (642-643) yılında Bükeyl b. Abdullah, Habib b. Mesleme ve Huzeyfe b. Esîd Selmân b. Rebîa'nın Bâb fatihi Sürâka tarafından Ermeniye'nin dağlık alanlarına gönderildiğini belirtir. ${ }^{31}$ Sebeos'un kayıtlarına göre Müslümanlar, Taron (Muş)'u geçtikten sonra Bznunik ve Aghiovit'ti almış Gogovit ve Bekri Vadisi'nden geçip Dvin'e yönelmişlerdi. Dvin yönetici ise bu akından tamamen habersizdi ve tüm birlikler Teodoros Rshtunik'in yanında olduğu için Dvin tamamen savunmasızdı. Hasat

\footnotetext{
${ }^{29}$ Ghewond, a.g.e., s. 8.

${ }^{30}$ Kaegi, a.g.e., s. 280.

${ }^{31}$ ibnü'l-Esîr, a.g.e., c. 2, s. 524; Detaylı bilgi için bkz. Mevlüt Koyuncu, "Müslüman Arapların İslam'ın Illk Fetihleri Döneminde İrminiyye İle Olan Münasebetleri", Tarihte Türkler ve Ermeniler (Ortaçağ), c. 2, TTK, Ankara 2014, s. 12.
}

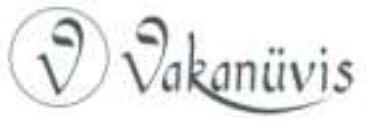


zamanı gelen insanlar da kaleye sığınmıştı. Bu yolculuklarında Müslümanlara Mokk Prensi Vardik rehberlik etmişti. Ermeni kaynaklarının belirttiğine göre Müslümanların Dvin'e saldırısında çok sayıda kişinin ölmesinin yanı sıra kadın ve çocukların da içerisinde yer aldığı yaklaşık 35 bin kişi esir edilmişti. ${ }^{32}$

Belâzurî́nin belirttiğine göre $\mathrm{Hz}$. Osman zamanında Habib b. Mesleme bölgede bazı yerleri ele geçirdikten sonra kendisine gelen Bağrevend patriğiyle belli miktar vergi verilmesi karşılığında, Müslümanlarla dost geçinmek ve onların düşmanlarıyla ittifak yapmamak şartıyla sulh tesis etti. Tiflis de aynı şekilde sulhla ele geçirilmişti. Debîl anlaşmasının metninden anlaşıldığına göre Müslümanlar burada da kimsenin malına ve canına dokunmadıkları gibi şehre ve kiliselere de her hangi bir zarar vermeyeceklerdi. Bu durum belirlenen cizye ve haracın ödenmesine bağlıydı. ${ }^{33}$ Tiflis anlaşması da benzer maddeleri intiva eder. Habib b. Mesleme anlaşma vesikasını Tiflis halkına, canlarının, kiliselerinin, havralarının, mabetlerinin ve dinlerinin teminatı olarak vermişti. Ancak bunlara dokunulmaması her aile için belirlenen bir dinar cizyenin ödenmesine bağlıydı. Tiflis halkı bu vergiyi azaltmayacağı gibi Müslümanlar da çoğaltmayacaktı. Ayrıca Müslüman karşıtı bir ittifaka girilmediği gibi Müslümanların düşmanlarına karşı savaşılacaktı ki bu madde Müslümanların bölge politikalarındaki asıl maksatlarını ortaya koymaktadır. Müslümanların başka şeylerle meşgul olduğu zamanlarda eğer Tiflis halkına düşman saldırırsa bu Müslümanların mesuliyetinde olmayacak, anlaşma da bu durumda bozulmuş sayılmayacaktı. ${ }^{34}$

Müslümanların buraya yönelik akınlarındaki öncelikleri vergi politikalarına dair yaptıkları anlaşma maddelerine de yansımıştır. Daha önce yaptıkları anlaşmalar gibi burada da ilk öncelik Müslümanlar aleyhine girişilecek ittifakları önlemekti. Bu durum özellikle Doğu Roma'ya karşı sınır güvenliği için çok mühimdi. Ancak Ermeni kaynaklarının yapılan anlaşmalardan ziyade pek çok ganimet ve

\footnotetext{
${ }^{32}$ Ghewond, a.g.e., s. 9; Sebeos, a.g.e., s. 108-109; Açogh'ıg de Daron (Asolik), Histoire Universelle Par Etienne Açogh'ig de Daron Traduite de I'armênien et Annotêe, Livre III, (Neşr: E. Dulaurier), Paris 1883, s. 152; Samouel D'Ani, Chronologiques, s. 401.

33 Belâzurî, a.g.e., s. 231; i̇bnü'l-Esîr, a.g.e., c. 2, 575.

${ }^{34}$ Belâzurî, a.g.e., s. 232-233.
}

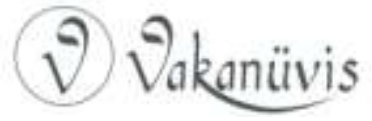


yaklaşı 35 bin esirin ele geçirilmesinden bahsetmesi bu akınların bir yağma akını olduğunu ortaya çıkarmaktadır. Buna rağmen kısa süre sonra bölgenin H. 26-27 (647)'de tekrar Doğu Roma hâkimiyetine girmesi ${ }^{35}$ ilk bakışta Müslümanların vergi politikaları ve kalıcı olmayan akınlarıyla Doğu Roma-Ermeni ittifakını önlemede başarısız olduğu yönünde bir sonucu akla getirmektedir. Bu fetihler her ne kadar Müslümanlara kısa süreliğine gelir getirmekten başka bir işe yaramasa $\mathrm{da}^{36}$ ilerleyen dönemdeki dini ve siyasi gelişmelerin Ermenileri Müslümanlara yakınlaştırması bu hususta Müslümanları bir kez daha haklı çıkaracaktı. Gösterdikleri dini hoşgörü ve düşük vergi uygulamaları Müslümanları Ermeniler için Doğu Roma'ya karşı bir dayanak haline getirdi. Ermeniler Müslümanlarla ilişkilerini güçlendirdikçe Doğu Roma'nın tehditlerinden etkilenmediği gibi tekliflerini de çekinmeden geri çevirebiliyordu. ${ }^{37}$ Diğer taraftan askeri olmaktan daha ziyade siyasal ve kültürel sonuçlar doğuran bu akınlarda Ermeni yerlileri Müslümanlara karşı pek de direniş göstermemişti. Bununla birlikte Müslümanlar da onlara karşı daha hoşgörülü yönetim ve vergi politikası takip ettiler. Zaten Doğu Roma ile dini ayrılıklar yaşayan Ermeniler Müslümanların bu politikasından memnun kaldı. Her hangi bir şekilde İslam dinine zorlanmadılar veya Müslüman kimliği içerisinde asimile de olmadılar. ${ }^{38}$ Müslümanlara bu coğrafyada rahat hareket imkânı veren de onların bu tutumuydu. Ermeniler bu sayede Sâsânî ve Doğu Roma baskısından da kurtuluyorlardı. ${ }^{39}$

Doğu Roma tahtında Herakleios'un ölümüyle gerçekleşen değişikliğin bölge politikalarına yansıması öncekilerden pek farklı olmadı. Yeni İmparator II. Konstans da önceki politikalara uygun olarak Ermeni beyleriyle ittifak arayışlarını devam ettirdi. Bu vesile ile Ermeni başkomutanı tayin edilen ve patricius ünvanı alan Teodoros Rshtunik

\footnotetext{
${ }^{35}$ Grousset, a.g.e., s. 288.

${ }^{36}$ Koyuncu, "a.g.m.", s. 14; Güney Kafkasya'ya yapılan bu ilk akınların asıl amacı bölgeden kazanılacak gelirler olmadığı açıktı. Her ne kadar bölge dağlık yapısına rağmen tarım ve hayvancılıkta gelişmiş olsa da bu durum Müslümanların ilgisini pek çekmedi. Hatta ticaret yollarına olan yakınlığı dahi Müslümanlar için pek fayda sağlamayacaktı. Bu sebeple Müslümanların Mezopotamya'da elde ettikleri hâkimiyeti burayla pekiştirmek istemeleri ilk amaçları olarak öne çıkmaktadır. Kaegi, a.g.e., s. 277.

${ }^{37}$ ipek, a.g.e., s. 13.

${ }^{38}$ Kaegi, a.g.e., s. 294-295.

${ }^{39}$ Ijpek, a.g.e., s. 19, 29.
} 
ilk etapta tam anlamıyla Doğu Roma yanlısı politika takip etti. Zaten anlaşıldığı üzere onun çıkarları için şimdilik bu yolu takip etmesi onun için en uygun olandı. Bu hususta en büyük destekçisi ise III. Nerses'ti. Bu ikili Müslümanların bölgedeki faaliyetlerine zıt olarak Doğu Roma himayesinden yanaydılar. Üstelik II. Konstans da onların bu sadakatini karşılıksız bırakmıyordu. Teodoros Rshtunik'in isteği üzerine daha önce Herakleios tarafından Afrika'ya sürgüne gönderilen Varazdirots Bagratuni ve oğlu spathar Simbat Bagratuni serbest bırakılarak merkeze dönmelerine izin verildi. ${ }^{40}$ Ancak Doğu Roma'nın politikaları güven vermiyordu ve Ermeni nakhararları her an bu sadakatten kopabilirlerdi. ${ }^{41}$ Beklendiği gibi de oldu. Illk isyan daha önce sürgüne gönderilmiş ancak II. Konstans'ın emriyle merkeze getirilmiş olan Aspet Varazdirots tarafından gerçekleştirildi. Ardından Teodoros Rshtunik'in ona itaat etmesi de gecikmedi. Nakhararların ardı ardına sadakatten ayrıldığını gören II. Konstans, Aspet Varazdirots'u mecburen kendisine gümüş tahtlar ve hediyeler göndererek Ermenistan kuropalatesi ${ }^{42}$ ilan etti. Ardından eşi ve çocuklarını da serbest bıraktı. Aspet Varazdirots da imparatora hizmetkâr olacağına dair mektup gönderdi. Fakat Aspet Varazdirots kısa süre sonra Dariwnk'te ölünce tüm yetkileri oğlu Simbat'a devredildi. Doğu Roma, Ermeni idaresinin elinden yavaş yavaş gittiğini görünce farklı bir plan devreye soktu. Rshtunik ve Bagratunileri birbirine düşürmek amaciyla Ermeni prensleri istese de istemese de Simbat'a verilen tüm yetkilerin aynısını Teodoros Rshtunik'e de verdi. Bunda Patrik III. Nerses'in imparatora ısrarı da etkili olmuştu. ${ }^{43} \mathrm{Bu}$ durum Müslümanlar için Ermenistan'da yeni gelişmelerin başlangıcıydı.

Bir yıl sonra H. 25 (645)'de Müslümanlar birkaç koldan Ermenistan'a akınlara başladılar. Sebeos Azerbaycan'da üçe ayrılan Müslüman birliklerinin Ayrarat, Sep'hakan Gund, ve Albanya'ya doğru hareket ettiklerini belirtir. Sep'hakan Gund'a giden birlikler burada çok sayıda

\footnotetext{
${ }^{40}$ Sebeos, a.g.e., s. 114.

${ }^{41}$ Grousset, a.g.e., s. 287.

4218 derece olarak sıralanan Doğu Roma ünvanları içerisinde en yüksek mevkide olan cesar ve nobilissimos'tan sonra kuropalates ünvanı gelmektedir. Bu ünvanlar çok sık olmamakla birlikte sadece imparatorluk ailesi mensuplarına verilmekteydi. Bkz. Ostrogorsky, a.g.e., s. 232.

43 Sebeos, a.g.e., s. 115-116; Yovhannēs Drasxanakertc'i, History of Armenia, (Translation and Commentary: Rev. Krikor H. Maksoundian), U.S.A. 1987, s. 102-103.
}

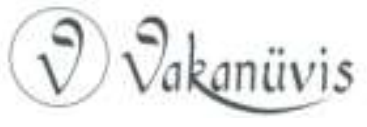


insanı kılıçtan geçirip Erevan Kalesi'ne ve Ordspoy'a başarısız akınlar düzenlemişlerdi. Bundan sonra su kenarındaki Artsap Kalesi'ni almak için harekete geçen birlikler kale karşısında ordugâh kurdular. Kale sakinleri Müslüman birliklerle baş edemeyeceklerini anlayınca kalenin arkasından Asoren'e doğru giden gizli geçitten çıkarak Darawn Kalesi'nden yardımcı birlik istemeye gittiler. Simbat Bagratuni bu yardım çağrısına oğlu Varaz Sahak emrinde 40 asker göndererek cevap verdi. Ancak Müslümanlar bu geçidi bulunca şafaktan önce herkes uyurken içeriye girip kaleyi ele geçirmeyi başardılar. Sebeos'a göre bu olaylar Kostant'ın 2. yılında yani H. 23 (643)'lerde gerçekleşmişti. ${ }^{44}$ Benzer akınlardan bahseden Ghewond ise Ukbe komutanlığındaki Müslüman birliklerin H. 30 (650-651) yılında Ermenistan sınırlarına ulaştığını belirtir. Bu birliklerin bir bölümü Vaspuragan'dan geçip Nahcivan kasabalarını ele geçirmiş, diğer bir bölümü Taron üzerinden devam etmiş, bir bölümü de Kogovit'ten geçerek Artsap Kalesi'ni kuşatmaya gitmişti. Ancak Müslümanlar kaleyi almayı başarmış olsa da beklenmedik bir saldırıya maruz kamışlardı. Doğu Roma yanlısı politikalarından vazgeçmemiş olan Prens Teodoros Rshtunik 600 adamıyla saldırıp 3 bin kişiyi öldürmüş ve esirleri kurtarmıştı. Üçe ayrılmış olan Müslüman ordusunun diğer birlikleri ise pek çok ganimetle Suriye'ye dönmeyi başarmıştı. Iki yıl süreyle akınlar durdurulmuştu. ${ }^{45}$ Diğer taraftan ancak çok az bir kısmı kaçmayı başaran Müslüman askerleri Shamp'da kendilerini güvence altına aldılar. Bu başarılı girişimden memnun olan Ermeni yöneticiler aynı şekilde Doğu Roma İmparatoru'nu da memnun etmede gecikmediler. Ele geçirdikleri ganimetlerden en seçkin yüz kadar atı II. Konstans'a hediye olarak gönderdiler. İmparator ve bütün saray bundan gayet memnun kalmış ve Teodoros Rshtunik'e teşekkürlerini bildirmişlerdi. ${ }^{46}$ Bölgedeki diğer yöneticiler de Doğu Roma yanlısı politika izlemeye devam etmişti. Albanya'nın Müslümanlar tarafından fethe başlandığı yıllarda Albanya yöneticisi Mehranîler hanedanından Varaz Grigor'un ikinci oğlu Cavanşir (637/8-680)'di. Sâsânîlerin Müslümanlar karşısında

\footnotetext{
${ }^{44}$ Sebeos, a.g.e., s. 116-118.

${ }^{45}$ Ghewond, a.g.e., s. 11-12; Asolik, a.g.e., s. 153; İslam kaynakları bir rivayete göre $\mathrm{H}$. 31 (651-652)'de Habib b. Mesleme'nin Ermeniye'yi fethettiğini kaydeder. Taberî, a.g.e., c. 4, s. 292; İbnü'l-Esîr, a.g.e., c. 2, s. 605.

${ }^{46}$ Sebeos, a.g.e., s. 118.
}

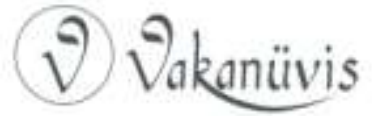


yenilmesiyle bölgede dağılan Sâsânî otoritesine karşı yerel yöneticiler ayaklanmaya başlamıştı. Bu sırada Doğu Roma yanlısı politika takip eden Cavanşir, II. Konstans'ın Müslümanlara karşı bölgede oluşturduğu ittifakta yer almaktan çekinmedii. ${ }^{47}$ Her ne kadar Müslümanlar için felaketle sonuçlanan ve akınların durmasına neden olan bu gelişmeler yaşansa da, diğer taraftan iki yıl süreyle Müslümanların bölgeyi tanıması ve politikalarını yeniden gözden geçirmeleri için iyi bir fırsat sunmuştu. Ayrıca Doğu Roma'nın kaderine terk edilen Ermenilerin bu zaman içerisinde yaşayacakları sıkıntılar onları tekrar Müslüman himayesine muhtaç bırakacaktı. Bu da iki yılın sonunda akınların tekrar başlaması için meşru bir sebep olacaktı.

İslam kaynakları H. 25 (645-646) yılı seferlerinin sebebini $\mathrm{Hz}$. Osman'ın Ukbe b. Ebî Muayt'ın Kufe'ye tayininden sonra Ukbe b. Ferkâd'ın Azerbaycan valiliğinden azl edilmesi ve bu sebeple buranın halkının önceki anlaşmayı bozmalarına bağlar. Velid Abdullah b. Şibl komutasındaki öncü kuvvetlerle Mukan, Beber ve Taylesan üzerine akınlar yapıp ganimet elde etti ve Azerbaycan halkı Huzeyfe döneminin barış şartlarını kabule zorlandı. Anlaşma gereği vergi olarak daha önceden olduğu gibi 800 bin dirhem altın alınmaya devam edildi. Daha sonra Selman b. Rabîa'nın ilerleyişinde de Erran ve Beylekân'ın da belli miktar vergi karşılığında can ve mal güvenlikleri sağlanmıştı. Bu süreçte Müslümanların bölgeye müdahalesi oradan gelecek her hangi bir siyasi tehdit nedeniyle değil daha çok önceki anlaşmaların yürürlükte kalmasını temine yönelikti. Bundan sonra askerlerini etrafa dağıtan Velid, Selmân b. Rebiâ'nın komutasında 12 bin kişilik bir kuvveti Ermenistan'a sefere gönderdi. Çok sayıda kişinin ölümü ve bol miktarda esirin ele geçirilmesiyle sonuçlanan bu akınlar sonunda Velid Musul yoluyla Küfe'ye doğru hareket etti. Ermeni kaynaklarıyla İslam kaynakları arasında tarihlerde bazı çelişkiler mevcut olsa da bu dönemde Müslümanların Doğu Roma'yla aralarındaki siyasi ve askeri çekişmelerin hat safhaya ulaştığı ve bu durumun Ermenistan halkını yakından ilgilendirdiği görülmektedir. Müslümanların asıl hedefi büyük bir orduyla gelmekte olan Doğu Roma'yı zamanında durdurmak bunu

${ }^{47}$ Büniyatov, a.g.e., s. 76, 90; Mehmetov, a.g.e., s. 167; Vəlixanlı, a.g.e., s. 24.

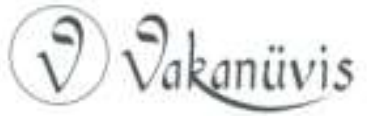


yaparken de bölge halkından gelebilecek olası saldırıları anlaşma yoluyla önlemekti. ${ }^{48}$

Sebeos bu dönemde İstanbul'la savaşmak isteyen Müslüman filosunun Doğu Roma birlikleri tarafından batırıldığını kaydeder. Her ne kadar Müslümanlar bu savaşlardan başarı elde edememiş olsa da genç yaştaki imparator II. Konstans'ın gözünü bir hayli korkutmuştu. Bu sebeple her iki taraf da anlaşma yolunu tercih etti. Ordunun da onayını alan II. Konstans, Procopios'u Muaviye ile görüşmesi için Şam'a gönderdi. Vergi miktarı ve sınırların belirlenmesiyle anlaşma sağlandı. ${ }^{49}$ Ancak Doğu Roma'nın bölgede güç kazanması Ermeniler için hiçte iyi sonuçlar doğurmadı.

Teodoros Rshtunik'in Procopios'la yaşadığı problem $^{50}$ nedeniyle sarsılan Ermeni-Doğu Roma ittifakı Teodoros Rshtunik'in bu kez Dvin'de önemli bir toplantıya başkanlık etmesiyle iyice çökme noktasına geldi. Bu toplantı bölgede yeniden hâkimiyet tesis eden Doğu Roma'nın bunu fırsat bilerek Grek Ortodoksluğu'nu Ermeni

\footnotetext{
${ }^{48}$ Belâzurî, a.g.e., s. 233, 374; Taberî bu fetihleri H. 24 (644-645) yılı olayları içerisinde ele alır. Taberî, a.g.e., c. 4, s. 246-247; ỉbnü'l-Esîr, a.g.e., c. 2, s. 573-575; i̇bnü'l-Kesîr, Velid b. Ukbe komutasında Azerbaycan ve Ermeniye'ye yapılan fetihlerin tarihi hakkında H. 24, H. 25 ve H. 26 yıllarına dair rivayetlerin varlığından söz eder. Savaş sebebi diğer kaynaklarda belirtildiği gibi halkın önceki anlaşma şartlarını yerine getirmemeleriydi. İbnü'l-Kesîr, a.g.e., c. 7, s. 238-247; Ya'kūbî ise H. 30 yılı olaylarını anlatırken Habib b. Mesleme'nin Ermeniye'nin bir kısmını fethettiğini ve sonrasında Hz. Osman'ın Selman b. Rebi'a'ya mektup yazarak onu bölgeye tayin ettiğini belirtir. O Beylekan'a kadar gelip buranın halkıyla belli vergi karşılığında anlaşma sağlamış ve ilerleyerek Berze'a'ya ulaşmıştı. Buranın halkıyla da Beylekan halkıyla yaptığı gibi bir anlaşma yapmıştı. Ya'kūbî, a.g.e., c. 2, s. 63; Ayrıca bkz. İbnü’l-Kesîr, a.g.e., c. 7, s. 259260.

${ }^{49}$ Sebeos, a.g.e., s. 118.

50 Doğu Roma Generali Procopios'la Teodoros Rshtunik'in aralarının bozulmasının sebebi Müslüman birliklerinin bölgeye yaptığı ilk akınlar sırasında Procopios'un duyarsız davranmasıydı. Procopios, Teodoros Rshtunik tarafından Müslüman birliklerinin bölgeye doğru hareket ettiği yönünde birkaç kez uyarılmış olmasına rağmen asker sayısına çok güvenerek ilave önlem almamıştı. Hatta Teodoros Rshtunik ısrarla kendisine birkaç kez de mektup göndermişti. Tüm bu uyarılara kulak asmak yerine bir de sinirlenerek elindeki sopasını Teodoros Rshtunik'e fırlatmış ve onun askerleriyle birlikte kendisinden ayrılmasına neden olmuştu. Kısaca Doğu Roma'nın Ermenileri aşağılayıcı devlet politikası generallerinin tavırlarına da yansımıştı. Ghewond, a.g.e., s. 7-8.
}

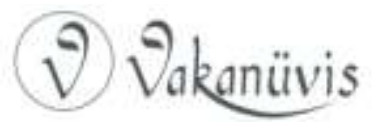


Kilisesi'ne dayatmaya yönelik önerisinin ${ }^{51}$ Ermenistan dini liderleri tarafından görüşülmek üzere bir araya gelmesinden oluşmuştu. Ermeni ruhban sınıfı Doğu Roma'nın önerisini kesin bir dille reddederek dini serbestlik mesajı verdi ancak bu aynı zamanda Ermenistan valisi Teodoros Rshtunik'in de sonu demekti. Tahmin edildiği gibi Doğu Roma İmparatoru hem askeri hem de dini anlamda anlaşamadığı Teodoros Rshtunik'i azlederek yerine H. 33 (653)'te Simbat Bagratuni'yi Ermenistan valisi yaptı. Bununla birlikte Teodoros Rshtunik'e gönderdiği mektupta birliklerini alıp Doğu Roma birliklerine katılmasını söyledi. Ancak görevden alınmasını içine sindiremeyen Teodoros Rshtunik oğlu Vart'ı göndererek Doğu Roma birliklerini yüzüstü bırakması hususunda tembihledi. Bu durum Doğu Roma'yı Müslümanlar karşısında yenilgiye uğratırken ${ }^{52}$ Ermeni yöneticiyi Müslümanlara daha da yanaştırıyordu. Ermeni ruhban sınıfı ve halkının bu yakınlaşmayı kabul etmesi hiç de zor olmamıştı. Çünkü Müslümanlar az bir vergi almanın yanı sıra her hangi bir dini dayatmayı da kendi politikaları açısından uygun görmüyorlardı.

Teodoros Rshtunik bu gelişmelerden sonra $\mathrm{Hz}$. Osman'ın valilerinden Muaviye'ye müracaat etmede tereddüt etmedi. Bir nevi bölgede hedefine ulaşan Müslümanlar ise özerklik ve serbestlik adına politikalarını bir adım öteye taşıdılar ve anlaşmanın süresini belirlemeyi Ermenilere bıraktılar. Müslümanlarla Ermeniler arasındaki anlaşmada şartlar tam manasıyla Ermenilerin lehine olacak şekilde kendilerine bırakıldı. Hatta Sebeos ve Ghewond'a göre üç yıl vergiden muaf tutulacak 3. yılın sonunda yine miktarı ve nevi kendileri belirleyeceklerdi. Anlaşma maddeleri gereğince Ermenilerin

\footnotetext{
${ }^{51}$ Doğu Roma bölgede sağlamlaştırdığı otoritesini fırsat bilip hemen Ermeniler üzerine baskıcı bir politika uygulamaya koyulmuştu. Roma askerleri II. Konstans'a ve patriğe yazdıkları şikâyet mektubunda bölge halkını kâfir olarak gördüklerini belirtiyorlardı. Gerekçeleri ise Khalkedon (Kadıköy) konsül kararlarının bölge halkı tarafından benimsenmemesi ve Leo'nun tapınağının kutsal sayılmamasıydı. Bunun üzerine II. Konstans ve patrik Ermenilerin inançlarını Romalıların inancıyla birleştirmeleri, konseyi kabul edip Tome'yi küçümsememelerine yönelik bir ferman çıkarılmasına karar verdi. $\mathrm{Bu}$ işi takip etmesi iç̧in Bagravanlı Felsefeci David'i görevlendirmişti. Bunun üzerine tüm Ermeni nakhararlar Dvin'de toplanıp görüşmeye karar verdi. Ermenilerin Doğu Roma ile mektuplaşmaları ve detaylı bilgi için bkz. Sebeos, a.g.e., s. 119-121; Asolik, a.g.e., s. 121-122.
}

${ }^{52}$ Sebeos, a.g.e., s. 119; Ghewond, a.g.e., s. 12-13; Grousset, a.g.e., s. 288-299.

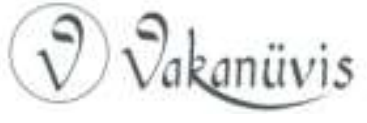


ülkelerinde besleyecekleri 15 bin asker Suriye hariç Müslümanların istediği yerlerde görev yaparak Ermenistan'a Müslümanların düşmanlarını sokmayacaktı. $\mathrm{Bu}$ askerlerin giderleri de vergiye sayılacaktı. Buna karşılık Ermenistan'a hiçbir Müslüman asker veya memur gönderilmeyecekti. Olası Doğu Roma saldırısında Müslümanlar yardım için büyük birlikler gönderecekti. Anlaşma maddeleri nakhararlar ve din adamlarınca oluşturulan kurulda kabul edildi ve Grigor Mamigonyan'la birlikte Simbat Bagratuni Halife'ye rehin olarak gönderildi. Vergi olarak da yıllık 500 gümüş dinar ödenmesi kararlaştırıldı. Bu anlaşma Muaviye'den sonra yerine gelen oğlu I. Yezid (680-683) döneminde de aynen yürürlükte kaldı. Ermenilerin tamamen serbestliğini öngören bu anlaşma Ermeni kaynakları tarafından anlamsız bir şekilde tepkiyle karşılanır. Sebeos, anlaşmayı deccalla ittifak olarak nitelendirirken anlaşmadan yaklaşık 2 buçuk asır sonra gelen Yovhannēs ise din adamları ve yöneticilerin yaptığı bu anlaşmayı ölüm üzerine yapılmış cehenneme sadakat yemini olarak görür. ${ }^{53} \mathrm{Her}$ ne kadar kaynaklar olayı böyle görse de araştırıcılar, Muaviye aracılığıyla hilafetten alınan ayrıcalıkların Sâsânîlerin daha önce bahşettiklerinden daha hoşgörülü olduğunu ve Müslümanların Hıristiyanlara Perslerden daha yakın davrandıklarını belirterek anlaşmanın hakkını teslim ederler. ${ }^{54}$ Zaten anlaşmadan anlaşıldığı üzere bu dönemde Müslüman karşıtı ittifaklar bittikçe vergilerin de azaldığı açıkça görülmektedir. Ayrıca tek öncelik bölgeye yönelik Doğu Roma akınlarının durdurulmasıydı. Müslümanların Ermeni yöneticilerden başka da bir talebi yoktu. Böylece Ermeniler Doğu Roma'nın kontrolünden çıktığı gibi Müslümanların egemenliğinden de çıkıp daha fazla özgürleşiyorlardı. Stratejik çıkarlar doğrultusunda yapılan bu anlaşma Müslümanların öteden beri savunduğu gibi Ermenistan'ın Doğu Roma'ya ait olmadığının resmi belgesi niteliğindeydi. ${ }^{55}$ Müslümanlara vergi ödemesi şartıyla Ermenistan, İslam Devleti'nin özerk bir bölgesi haline geldi. Müslüman hâkimiyeti İberia yöneticisi II. Stephan ve Albaniya yöneticisi Juansher tarafından

\footnotetext{
${ }^{53}$ Sebeos, a.g.e., s. 138; Ghewond, a.g.e., s. 13-14; Yovhannēs, a.g.e., s. 103.

${ }^{54}$ Grousset, a.g.e., s. 289.

${ }^{55}$ Kaegi, a.g.e., s. 293-294.
} 
da kabul edildi. Böylece Tiflis Müslüman yerleşim bölgelerinden biri oldu. ${ }^{56}$

Halife'nin 653 yılında Güney Kafkasya'da hâkimiyet kurma girişimlerinin Ermeni feodallerin vassal olmaya zorlanması, savaş, göç ve yok olmayla sonuçlandığı ileri sürülmektedir. Bu tabiiyet uzun zaman içerisinde çeşitli Ermeni grupların hilafetten daha fazla imtiyaz koparma yarışını körüklemiş ve zaman zaman ayaklanmalara neden olmuştu. Hilafete karşı ayaklanmanın en şiddetlilerinden biri ise anlaşmadan yaklaşık 120 yıl sonra 25 Nisan 772'de Bagratunilerin yenilgisiyle sonuçlanan ayaklanmaydı. Bundan sonra Ermenistan daha sonra krallık statüsüne çıkacak olan Bagratuni, Mamigonyan ve Ardzıruni aileleri arasında daha belirgin bir şekilde bölünmüştü. Bu bir bakıma Ermeni topraklarında var olan ve birbirlerinden bağımsız olan ailelerin statüsünü devlet statüsüne çıkarmıştı. ${ }^{57}$ Tüm bu gelişmeler Emevilerden sonra Abbasilerin bölgede hakemlik görevini sürdürmesine hatta bölgede Abbasilere bağlı yeni Türk devletinin kurulmasına kadar devam eden süreci etkilemişti. ${ }^{58}$

Doğu Roma'nın kontrolü dışında ve tamamen çıkarlarına aykırı bu gelişmeler II. Konstans'ın bir hayli tepkisini çekmiş ve yaklaşık 100 bin kişilik ordusuyla Ermenistan'a yeni bir akın düzenleyerek Müslümanların uyarısına rağmen Erzurum'a gelmesine neden olmuştu. Tercan'a vardığında Halife ona Ermenistan'ın kendisine ait olduğunu ve oraya girmemesi gerektiğini bildiren bir mektup göndermişti. Ayrıca bu uyarıya uymadığı takdirde bunun karşılıksız kalmayacağını ve oradan kesinlikle kaçamayacağını da bildiriyordu. Ancak II. Konstans da Ermenistan'ın kendisine ait olduğunu bildiren bir mektup gönderdi. ${ }^{59}$ Ermenistan'a geldiğinde Gürcistan'dan başka kendisine itaat eden

\footnotetext{
${ }^{56}$ Cyril Toumanoff, "Armenia and Georgia", The Cambridge Medieval History, Vol. IV, The Byzantine Empire part I, Cambridge 1966, s. 605.

${ }^{57}$ Toumanoff, "Introduction to Christian Caucasian History II States and Dynasties of the Formative Period", Traditio, Vol. 17 (1961), s. 7; 771/772 ayaklanması ve sonuçları için bkz. Ghewond, a.g.e., s. 135-146; Grousset, a.g.e., s. 310-320.

58 Azerbaycan merkezli bölgede 889-929 yılları arasında hâkim olan Sâcoğulları hanedanı için bkz. Hakkı Dursun Yıldız, "Sâcoğulları", Doğuştan Günümüze Büyük İslam Tarihi, c. 6, İstanbul 1989, s. 81-136; İpek, "Sâcoğulları", DiA, c. 35, 2008, s. 364-366.

59 Subaşı, "Bizans İmparatorlarının Theodosiopolis ve Çevresindeki Faaliyetleri", Turkish Studies, Volume 5/3, 2010, s. 1836.
}

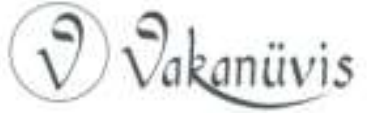


bölge olmadığı fark etmişti. Çünkü tüm Ermeni feodalleri Müslüman yanlısı politikadan yanaydı. Diğer taraftan Teodoros Rshtunik karşıtı olan başta III. Nerses ve bazı ileri gelenler II. Konstans'ın yanında yer almakta gecikmedi. Ermenistan'ı yağmalamaması için yalvarışta bulunmalarına rağmen, her ne kadar Yovhannēs bu çabaların olumlu sonuç verdiğini belirtse de, II. Konstans'ı Ermenistan'ı yağmalama fikrinden tam anlamıyla vazgeçirememişlerdi. Doğu Roma eline geçen fırsatı yine değerlendirmiş ve itirazlara rağmen Dvin'e gelerek baskıcı din politikalarını uygulamaya koymuştu. Grek din adamları Ermeni kiliselerinde Khalkedon (Kadıköy) konsülüne uygun konuşmalar yaptı. Ermeni din adamları ve idareciler bundan memnun olmasa da zorla kutsal ayinden geçirildiler. Diğer taraftan II. Konstans beklendiği gibi Teodoros Rshtunik'i görevden alarak yerine başkasını atamıştı. Bu azli kabul etmeyen Teodoros Rshtunik gönderilen adamları yakalayarak Bağhes Kalesi'ne hapsetti. Kendi de güvenliği için Akdamar adasına çekildi. Ermenistan'da hâkimiyeti tam olarak tesis edemeyeceğini anlayan II. Konstans kızgınlığıyla pek çok yeri talan etmekle yetindi. Muşeğ Mamigonyan'ı Ermeni birlilerinin başına tayin edip İstanbul'a dönmek için Dvin'den ayrılmıştı. Beraberinde Dvin'den ayrılan III. Nerses ise Teodoros Rshtunik ve diğer nakhararlardan korkusundan Tayk'da kalmayı tercih etti. Bu sırada Akdamar'a çekilmiş olan Teodoros Rshtunik saklandığı yerden çıkarak bu kez Müslümanlarla daha sıkı bir ittifak yaptı. Damadı Mamigonyan lordu Hamazaps'la birlikte Müslümanlardan aldıkları 7 bin kişilik birlikle birlikte pusuya yattı ve Ağiovit ve Pznunik'te konuşlandı. Her hangi bir yerde konaklayamayan Doğu Roma birlikleri ise Karadeniz kıyılarındaki kaçışları sırasında başta Trabzon olmak üzere pek çok yeri talan edip yıktılar. Teodoros Rshtunik ise Şam'da ikamet eden Hz. Osman'ın valisi Muaviye'nin huzuruna çıkarak bu ittifakı iyice pekiştirdi. Bu her zaman ki gibi Müslümanlar için iyi bir gelişmeydi. Bu kez Müslümanlar Ermenistan'a gitmiyor bizzat Ermeni yöneticiler Şam'a gelip itaat arz ediyor ve Doğu Roma'ya karşı yardım talep ediyordu. Bu buluşma karşııklı anlaşmadan ziyade Teodoros Rshtunik'in tam anlamıyla taltif edilmesine yönelikti. Altın ve gümüş işlemeli kıyafet giydirilen ve sancağın yanı sıra çok çeşitli hediyeler alan Teodoros Rshtunik Muaviye tarafından Ermenistan, Gürcistan, Albanya ve Kafkas geçitlerine kadar tüm bölgenin yöneticisi kabul edildi. Ayrıca H. 34-35 (654-655)

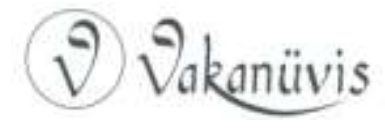


yıllarında Dvin'e kadar gelen Müslüman birlikler bu otoriteyi diğer yöneticilere de kabul ettirip geri döndüler. Tüm bu gelişmeler Muaviye ile II. Konstans'ın aralarındaki anlaşmanın yürürlükten kalkması anlamına geliyordu. Muaviye İstanbul'u ele geçirip Doğu Roma'yı ortadan kaldırmak için tüm birliklerine batıda toplanma emri verdi. ${ }^{60}$ Bu gelişmeler Doğu Roma'nın Ermeni politikalarını yeniden gözden geçirmesi gerektiğini ortaya koydu. Ermenilere karşı bu baskı politikasının sonucu beklendiği gibi yararlarına olmadı. Hatta tartışmaya yatkın olan Ermenilerin Müslümanlar karşısında yeterli bir savunma gücü olarak kullanılamayacağını daha da iyi anlamış oldular. ${ }^{61}$ Böylelikle Doğu Roma'nın Ermenistan'ı ele geçirme çabaları başarısızlıkla sonuçlanıyordu. Özellikle II. Konstans'ın girişimleri Doğu Roma ile Ermeniler arasındaki etnik ve dini ayrım nedeniyle sonuçsuz kaldı. Buna bir de Doğu Roma'nın bu yüksek arazide giriştiği savaşlarda düştüğü taktiksel, stratejik ve lojistik hatalar eklenince ${ }^{62}$ Müslümanların bölgede ilerleyişinin önü iyice açılmış oldu.

Muaviye'nin İstanbul Seferi'nde Doğu Roma karşısında yenilip Kadıköy'ü terk etmesi üzerine Müslüman birlikler geri dönüp Dvin'de kamp kurmuşlardı. Burada Gürcistan'a "Ya bizim hizmetimize girersiniz yâda ülkeyi terk edersiniz." şeklinde bir mektup gönderdiler. Ancak Gürcistan halkı bunu kabul etmemiş ve savaş hazırlığı yapmışlardı. Ancak harekete geçen Müslümanlar kış şartları nedeniyle geri dönmek zorunda kalmıştı. Bu sırada Ermeni yöneticileri Hamazasp ve Muşeğ Mamigonyan aralarında kan dökmemek için bir araya gelip barış yaptılar. Barış şartları arasında süvari sayısına göre ülkenin bölünüp altın ve gümüş vergi miktarları belirlendi. Bu da Akdamar'da hasta yatan Teodoros Rshtunik'in gelirinin elden çıkması demekti. Bunun üzerine Teodoros Rshtunik Ermeni ve Gürcülere saldırmak için müttefiki Müslümanlardan yardım istedi. Müslümanlar bir kez daha Ermenistan'ın bölünmesini önlemek için hareke geçecek ve feodal kavgalarda arabulucu olacaktı. Doğu Roma metbûluğunu benimseyemeyen Muşeğ Mamigonyan da Müslümanların hizmetine girmeye karar verdi. Teodoros Rshtunik'in ve diğer Ermeni prenslerinin

\footnotetext{
${ }^{60}$ Sebeos, a.g.e., s. 137-143; Yovhannēs, a.g.e., s. 103-104.

${ }^{61}$ Kaegi, a.g.e., s. 279.

${ }^{62}$ Hewsen, Armenia, s. 105.
} 
desteğini alan Müslüman birlikler bir baştan bir başa Ermenistan'ı ele geçirdiler. Ancak ağır kış şartları Arakadzodın'de Aruch'ta ikamet eden Habib b. Mesleme'nin komutasında bulunan Müslüman birliklerin ilerleyişini bir hayli zora soktu. Kışın sonuna doğru Aras Nehri'ni geçip Zarehavan'da konaklamaya karar verdiler. Bunun üzerine General Mavrianos komutasındaki Doğu Roma birlikleri rahatlıkla Dvin'i kuşatıp Nahçıvan'a ulaştılar. Ancak baharda toparlanmış olan Müslüman birlikler saldırıya geçip onların çoğunu kılıçtan geçirdi. Sağ kalanlar etrafa kaçışırken Mavrianos Gürcistan'a doğru kaçtı. İlerleyen Müslüman birlikleri ise Karin (Erzurum)' $\mathrm{e}^{63}$ varıp pek çok ganimet elde ettiler. Bu mücadelelerde Müslümanlar Ermenistan, Sünik ve Albanya'da pek çok hazineyi ele geçirmişlerdi. Ayrıca ileri gelenler aileleri ile birlikte rehin olarak alınmıştı. Hasta olan Teodoros Rshtunik de Şam'a getirilmiş ancak bir yıl sonra ölünce ata mezarlığına gönderilip gömülmüştü. ${ }^{64}$

$\mathrm{Bu}$ gelişmelerden sonra ölen Teodoros Rshtunik yerine Ermenistan yöneticiliğine Müslümanların desteğiyle Hamazasp Mamigonyan geçmişti. Gelişmeleri yakından takip eden Doğu Roma onu Müslümanların eline bırakmamak için hareke geçti ve gümüş bir taht göndererek 657-658' de kuropalates ilan etti. Ayrıca diğer prenslere de hediyeler sunup onları kendi tarafına çekmeye çalıştı. Doğu Roma böylece Ermenileri kendi boyunduruğuna sokmayı başarmıştı. Bu tayinde de III. Nerses'in etkisi büyük oldu. Yovhannēs'e göre Mamigonyan Müslümanların boyunduruğunda olmanın getirdiği külfet nedeniyle Doğu Roma'nın boyunduruğuna girmeye karar vermişti. Sebep ne olursa olsun Müslümanların bölge politikası bir anda çökmüştü. Daha önce Doğu Roma'ya karşı kendi yanına çekmeyi başardığı Ermeniler bir anda karşı safa geçmişlerdi. Müslümanlar bir an önce tedbirler alıp durumu tekrar kendi lehlerine çevirmek zorundaydılar. Ancak bu defa izleyecekleri yol haliyle öncekilerden farklı ve sert olacaktı. Beklendiği gibi ilk tepkileri büyük olan Müslümanlar ellerindeki rehinelerin bir kısmını idam ederek gözdağı vermiş ve Hamazasp Mamigonyan'ın tekrar itaatini sağlamaya

${ }^{63}$ Erzurum ve çevresi bundan sonra yeni çehreye bürünerek Anadolu'da en önemli İslam merkezlerinden biri oldu. Bkz. Subaşı, "Theodosiopolis", s. 1837.

${ }^{64}$ Sebeos, a.g.e., s. 143-150; Yovhannēs, a.g.e., s. 104.

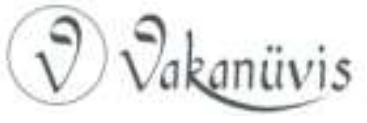


çalışmıştır. Muşeğ Mamigonyan ise 4 oğlu hala rehine olduğu için itaat etmekteydi. ${ }^{65}$ Ermenistan'da bunlar yaşanırken Azerbaycan'da gelişmeler olumluydu. Muaviye'nin hilafeti ele geçirmesinden önce $\mathrm{Hz}$. Ali (H. 35-40/656-661)'nin halifeliğinin ilk yılında Eş'as ibn Kays Azerbaycan'a gönderilmişti. Bu dönemde Azerbaycan halkının çoğunun Müslüman olduğu ve Kuran-ı Kerim okuduğu anlaşılmaktadır. Eş'as ibn Kays divanlardan atâ alan Araplardan bir kısmını Erdebil'e yerleştirmiş ve buranın gelişimine büyük katkı sağlamıştır. Erdebil bir yandan şehir haline gelirken diğer yandan da süratle İslamlaşıyor ve Müslümanlık burada kalıcı bir din haline geliyordu. Bu dönemde buraya bir de cami yapılmış ve bu cami zamanla ihtiyaca cevap veremeyince genişletilmişti. ${ }^{66}$

\section{Müslümanların Emeviler Dönemi Bölge Politikaları}

Muaviye'nin halife olmasıyla birlikte Emevilerin İslam Devleti'nde idareyi ele alması birtakım gelişmeleri beraberinde getirmiş olmasına rağmen Güney Kafkasya politikalarında pek bir değişiklik gözlenmez. $\mathrm{H}$. 40 (661)'da Müslümanların Ermenistan'da yeniden hâkimiyet tesis etmesi Ermeni kaynaklarının da ittifak ettiği gibi bölgeye tam bir hoşgörü ve refah getirmişti. Halife Muaviye nakhararlar ve Patrik III. Nerses'in teklifiyle yanında rehin tuttuğu Grigor Mamigonyan'ı Ermenistan'a işkhan atadı. Hamazasp Mamigonyan'ın kardeşi olan bu yeni işkhan 662'den 685'e kadar tam 23 yıl ülkede iyi bir yönetim sergiledi. Müslümanların bu hoşgörü politikası sayesinde hem Doğu Roma'nın Ermeniler üzerindeki baskısı durdurulmuş hem de pek çok kalkınma faaliyetleri gerçekleştirilmişti. Ghewond'un tabirine göre Ermenistan büyük bir huzurun tadını çıkarıyor, Ermeni Hristiyanlar hiçbir baskı görmeden hayatlarını devam ettiriyorlardı. Ayrıca ă̆ır

\footnotetext{
${ }^{65}$ Sebeos, a.g.e., s. 151-152; Yovhannēs, a.g.e., s. 104; Asolik, a.g.e., s. 127.

${ }^{66}$ Belâzurî, a.g.e., s. 375; Ya'kūbî, a.g.e., c. 2, s. 103; ìbnü'l-Kesîr, a.g.e., c. 7, s. 365369; Atâ, Hz. Ömer döneminde kurulan divandan Müslümanlara yılda bir defa cizye, haraç ve ticaret mallarından gelen gelirlerden dağıtılan paraya denilmektedir. Bu terim Emevilerde ve Abbasilerde askerlerin maaşları için kullanılmaya başlandı. Hz. Ömer zekât dışı olan bu gelirleri her ay erzak ve yılda bir kez para olarak geliri olmayan Müslümanlara dağıtmayı uygun bulmuştu. Bkz. Mustafa Fayda, "Atâ", DiA, c. 4, 1991, s. 33-34.
}

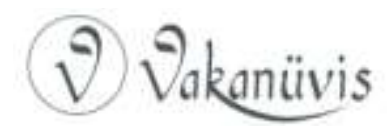


vergiler altında da ezilmiyorlardı. ${ }^{67}$ Böylece Ermenilerle birkaç yıl önce Doğu Roma nedeniyle bozulan ilişkiler tekrar normale dönüyordu.

Muaviye'yle birlikte Emevi hanedanın hilafete geçmesi yerel yöneticileri politikalarını yeniden gözden geçirmeye ve yeni yönetimle iyi geçinmeye sevk etti. Doğu Roma'dan beklediğini bulamayan Cavanşir Azerbaycan'a olası saldırıları önlemek için Muaviye'yle görüşmek için 667 ve 670 yılarında Şam'a gitmişti. Bu görüşmelerde Albanya hilafete bağlı bir devlet haline geldi ve vergi miktarı üçte bir oranında azaltıldı. Ancak burada Muaviye'nin bu politikasına hem ülke içindeki hem de sınırlarda yaşanan hadiseler etki etmişti. Hz. Ali ile aralarında yaşanan olaylar ve Doğu Roma ile devam eden çarpışmalar Muaviye'yi Kafkasya'daki problemleri anlaşma yoluyla bertaraf etmeye sevk etmişti. ${ }^{68}$

Bu sıralarda Müslümanlar Gürcistan'a da bazı akınlarda bulunuyordu. Gürcü kaynağı, Hülefa-i Raşid'in döneminden Emevilerin ilk dönemlerine kadar bölgede yaşanan Müslüman-Doğu Roma çekişmelerinde Gürcistan yöneticisinin II. Stefanos (Stephanos) (639663) olduğunu belirtir. Hz. Ebu Bekir, Doğu Roma İmparatoru Herakleios tarafından epey tahrip edilmiş olan Sâsânî topraklarına girmiş ve bu ilerleyiş daha sonraki halifelerle birlikte Filistin'e kadar devam etmişti. Müslümanların önünden kaçan Sâsânîlerin bir kısmı Herakleios'un daveti üzerine Doğu Roma'ya sığınmışlardı. ${ }^{69}$ II. Stefanos'tan sonra yerine bütün hazinesini paylaştığı Mir (663-688) ve Arçil (668-718) adında iki oğlu geçmişti. Bu dönemde bazı kaynakların yanlış olarak $\mathrm{Hz}$. Muhammed'in yeğeni olarak nitelendirdiği Kura Mervân ${ }^{70}$ Halife Hişam tarafından Gürcistan'a gönderilmişti. Doğu

67 Ghewond, a.g.e., s. 14; Grousset, a.g.e., s. 293; Yovhannēs, a.g.e., s. 105; Azerbaycan'ın Muaviye'nin halifeliği döneminde H. 53 (672-673) yılında haracı 30 milyon dirhemdi. Ya'kūbî, a.g.e., c. 2, s. 143.

${ }^{68}$ Vəlixanlı, a.g.e., s. 24.

${ }^{69}$ Gürcistan Tarihi, s. 197-199; Kartlis Tskhovreba, s. 110-111.

70 David Marshall Lang, Mervân'a sağır manasında kura denilmesinin sebebini Gürcü Kroniğine dayandırarak yenilenlerin eman dilemelerini ve bağışlanma taleplerini duymamazlıktan gelip umursamamasına bağlamaktadır. David Marshall Lang, Eski Halk ve Ülkeler, Gürcüler, (Çev: Neşenur Domaniç), İstanbul 1997, s. 93; Ancak Gürcü Kroniği bunun sebebini Mervân'ın müşavirlerini dinlememesi ve makul tavsiyeleri dikkate almaması olarak izah eder. Ayrıca Mervân'ın Hz. Muhammed'in gerçekten yeğeni olmadığı ve bölgeye geliş tarihiyle alakalı açıklamalar için ayrıca bkz. Gürcistan

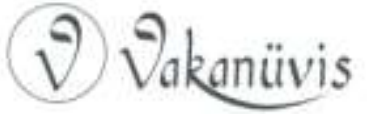


Roma ve onların en büyük destekçilerinden Ermenilerle savaşıp pek çok esir aldıktan sonra kuzeye doğru ilerlemişti. Onun bu ilerleyişi karşısında bütün Gürcü senyörlerin akrabaları, mtavarlar, peteakhşlar ve eristavlar Kafkasya'daki kayalık ve mağaralara sığınarak kendilerini emniyete almışlardı. Kura Mervân bu ilerleyişinde Derbent kapılarını ve pek çok Gürcü kalesini zapt etti. Samtzhe'ye oradan da Odzhe'ye geçerek karargâh kurdu. Daha sonra Arguetli'ye gönderdiği öncü kuvvetleri Gürcü aile şefi olan David ve Konstantine ile savaştı. Ancak bu kuvvetler burada büyük bir yenilgi aldı. Duruma kızan Mervân "Dayım Muhammed'e karşı gelen de kim oluyor" diyerek çok sayıda Müslüman askerini bölgeye sevk etti. David ve Konstantine zincire vurularak Mervân'ın huzuruna çıkarıldı. Müslüman olmaları teklifini ret edince göle atılarak öldürüldüler. Mervân bundan sonra Gürcü topraklarında ilerlemesine devam ederek Gürcü kralları Mir ve Arçil'in bulunduğu Anakof Kalesi'ni kuşattı. Mir ve Arçil'in yanında bin kadar eristav ve peteakhş ve 2 bin kadar Aphaz savaşçı bulunmaktaydı. Bu arada Müslümanlar arasında yayılan dizanteri 35 bin askerin ölümüne neden oldu. Diğer taraftan saldırıya geçen Gürcü krallar da 3 bin kadar Müslüman askerini öldürdü. Mir bu savaşta yaralanmıştı. Bu sırada Müslüman ordusu sel felaketine de maruz kaldı. Kura Mervân bu felaketle aldığı ağır kayıplarla bölgeyi terk ederek Erzurum'un İspir ilçesine doğru çekildi. ${ }^{71}$

Abdülmelik b. Mervân (H. 65-86/685-705)'ın ikinci yılında bazı iç karışıklıklar meydana gelmiş, H. 66 (685-686) yılında Muhtâr'ın Küfe'de ayaklanması Ermeniye ve Azerbaycan yönetiminde değişikliklere neden olmuştu. Hedefinde Hz. Hüseyin'in katilleri olan Muhtâr, Eşter'in kardeşi Abdullah b. Hârise'yi bir sancakla birlikte Ermeniye'ye, Muhammed b. Umeyr b. Utarid'i ise Azerbaycan'a gönderdi. Daha sonra isyanı bastıran Mus'ab, H. 67 (686-687) yılında Musul, Cezîre, Ermeniye ve Azerbaycan'a Mühelleb b. Ebi Süfre'yi gönderdi. ${ }^{72} \mathrm{Bu}$ karışıklıklar Güney Kafkasya'da başka aktörlerin de yer almasına zemin

Tarihi, s. 202, 208'deki Hususi Notlar; Kartlis Tskhovreba, s. 111-112; Subaşı, "Arap Fethinden Selçuklu Hâkimiyetine Artvin", Turkish Studies, Sayı: 7/3, 2012, s. 2334 dp. 31;

${ }^{71}$ Gürcistan Tarihi, s. 202-206.

72 Detaylı bilgi için bkz. Taberî, a.g.e., c. 6, s. 34-116; Ya'kūbî, a.g.e., c. 2, s. 175-176; ibnü'l-Esîr, a.g.e., c. 3, s. 566, 608.

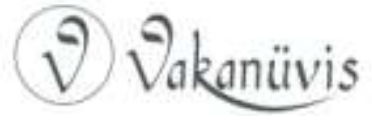


hazırladı. Karışıklıklardan istifade eden Ermeniler, Gürcüler ve Albanyalılar isyan ederek 30 yıldan beri ödedikleri vergiyi kesmişlerdi. Ancak bu isyanı 3 yıl kadar devam ettirebildiler. Dördüncü yılda Hazarlar Ermenistan'a saldırıp Grigor'la birlikte pek çok Gürcü ve Alban prensini öldürdüler. Pek çok yeri yağmalayan Hazarlar ganimet ve esirlerle ülkelerine geri döndüler. ${ }^{73}$ Bu gelişmelerin yegâne sebebi Doğu Roma'nın çeşitli halkları ve Kafkasya'daki tampon devletler olan Alanlar, Abhazlar ve Ermenileri gerek birbirine düşürmek gerekse Müslümanlara karşı kışkırtmayı diplomatik bir görev olarak benimsemesiyle alakalıydı. ${ }^{74}$

Abdülmelik b. Mervân'ın Kıbrıs'a dair Doğu Roma'yla yaptığı anlaşmaya göre Kıbrıs'ın bir yarısından Emeviler diğer yarısından Doğu Romalılar vergi alacak ayrıca Ermenistan, Gürzan, Arzan ve Azerbaycan Doğu Roma'ya kalacaktı. Böylece Ermeniye ve Gürcistan'ın gelirlerini de aralarında paylaşmayı kabul ettiler. Ancak bu anlaşmanın II. Justinianos (685-695, 705-711) tarafından bozulması Emevilerin bölge politikaların yeniden gözden geçirmesine neden oldu. II. Justinianos Halife'nin itirazına rağmen Kıbrıslıların bir kısmını İstanbul kuşatmasında sıkıntı yaşadığı ve denizcilere ihtiyaç duyduğu Kyzikos'a yerleştirmişti. Bu gelişme 691 yılında iki tarafı Ermeniye'de Sebastopolis (Sivas ve Amasya arasında Sulu Saray)'de karşı karşıya getirmiş ve Doğu Roma'nın ağır yenilgisiyle sonuçlanmıştı. Böylece Ermeniye'de üstünlük tekrar hilafete geçti. ${ }^{75}$

Bölgede baş gösteren isyanlar Müslümanların Ermenistan'daki yönetime bakışını değiştirdi ve Mamigonyanlar yerine Bagratunilerden Aşot bölgeye vali tayin edildi. Onun Müslüman desteğiyle atanması Doğu Roma'nın hiç hoşuna gitmemişti. Ermenileri tekrar kendi tabiliğine almak isteyen II. Justinianos tahta geçişinin ikinci yılı olan 687 'de büyük bir kuvveti Ermeniler üzerine gönderdi. Ghewond'un bu yıl içerisinde görülen kuyruklu yıldızın açlık ve şiddete yorumlandığını belirten kaydı taraflar arasındaki çekişmelerin özeti gibiydi. Pek çok

\footnotetext{
${ }^{73}$ Ghewond, a.g.e., s. 15-16; Samouel D'Ani, Chronologiques, s. 409.

${ }^{74}$ Norwich, a.g.e., s. 284.

${ }^{75}$ Gregory Abû'l-Farac, Abû'l-Farac Tarihi, c. II, (Süryanice'den İngilizceye Çeviren: Ernest A. Wallis Budge), (Türkçeye Çeviren: Ömer Rıza Doğrul), TTK, Ankara 1999, s. 187-188; Ostrogorsky, a.g.e., s. 121, 123; Norwich, a.g.e., s. 269.
}

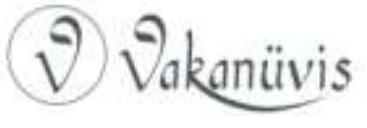


kişiyi esir eden Doğu Roma Strategosu Leontios bununla da yetinmeyip ödeme gücü olanları vergiye bağladı. Her tarafı yağmalayıp yıkan II. Justinianos geri döndü ancak ülkesinde bir isyanla karşılaştı. Asizadeler onu tahtan indirip burnunu kesmişti. Onun Hazar hakanının kızıyla evlenmesi ve onlardan yardım alıp yeniden tahtı ele geçirmesi bölge tarihinde yeni bir dönemi başlattı. Artık Doğu Roma-Hazar ilişkisi hem Ermeniler hem de Müslümanlar açısından farklı sonuçlar doğuracaktı. Diğer taraftan Müslümanlar da Doğu Roma birliklerini bölgeden uzaklaştırmak için akınlar düzenleyerek pek çok ganimet ele geçirmişlerdi. Bu mücadelelerin sonunda 690'da Aşot ölmüştü. Doğu Roma orduları bir defa daha Ermenistan'a girerek Gürcistan ve Albanya'ya kadar ilerlemiş ve yerel yöneticiler itaate zorlanmıştı. Hatta bunun için onlardan rehineler dahi istenmişti. ${ }^{76}$

Diğer taraftan Doğu Roma'nın bu kez Hazarlar vasıtasıyla bölgeye müdahalesi ve bir nevi Hazarları Ermenilere karşı kışkırtması Emevilerin bölge politikalarını sertleştirmesine neden olmuştu. 693'te Muhammed ibn Mervân'ı mağlup eden Hazarlar ancak yeğeni Mesleme tarafından geri püskürtülmüştü. Bu sırada Doğu Roma tarafından katledilen Varazdirots'un oğlu Simbat Bagratuni'nin hem babasının hem de ailesinin intikamını almak istemesi Ermenilerle Müslümanları bir kez daha yakınlaştırdı. Diğer taraftan Müslümanların başarıları Ermenistan Patriciusu Symbatios'un bölgeyi Müslümanlara teslim etme kararında son derece etkili oldu. Gelişmeleri takip eden Doğu Roma İmparatoru III. Tiberios Apsimares (698-705)'in Simbat'ın yakalanması için gönderdiği ordu Erzurum yakınlarında Payik ovasında ağır kayıplar verdi. Çok kanlı geçen mücadelede her iki taraf da ağır kayıplarla geri çekilmek zorunda kaldı. ${ }^{77}$ Bununla birlikte H. 73 (692693) yılında Mervân b. Muhammed'in Doğu Roma kuvvetlerini bozguna uğratması ve aynı yıl içerisinde Osman b. Velîd'in 4 bin kişilik kuvvetiyle Ermeniye'de 60 bin kişilik Doğu Roma birliğini bozguna uğratması önemlidir. ${ }^{78}$ Ancak Ermeni kaynakları Ermeni prenslerinin

\footnotetext{
${ }^{76}$ Ghewond, a.g.e., s. 17-18; Grousset, a.g.e., s. 295-296.

${ }^{77}$ Ghewond, a.g.e., s. 19.

${ }^{78}$ Taberî, a.g.e., c. 6, s. 194; ìbnü'l-Esîr, a.g.e., c. 4, s. 58; ìbnü'l-Kesîr, a.g.e., c. 8, s. 551-552; Ebü'l-Abbâs Şihâbüddîn Ahmed b. Abdilvehhâb b. Muhammed e-Bekrî etTeymî el-Kureyşî en-Nüveyrî, Nihâyetü'l-ereb fî Fünûni'l-edeb, c. 21, (Tahkik:
}

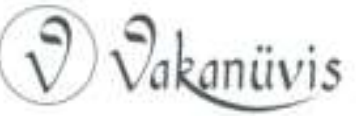


Doğu Roma tahakkümünden kurtarılması olaylarını İslam kaynakları gibi değerlendirmez. Bu dönemin gazaları Müslümanların Ermenilere uyguladığı hoş görü politikalarının da sonu olarak görülür ve Mervân'ın Mogk eyaletinin bir kısmında katliam yaptığı, iki yıl sonra da Pakavan'da meşhur bir kiliseyi yağmaladığı Ghewond'un kayıtlarında bu vesileyle geniş yer bulur. ${ }^{79}$

Ermenistan'da karışıklığın devam ettiği bu yıllarda Mervân b. Muhammed Suriye'ye gidince yerine Ebu Şeyh b. Abdullah (701-703)'। bırakmıştı. Ghewond onun soyluları ve onların süvarilerini bölgeden uzaklaştırma niyetinde olduğunu belirtir. Hatta çoğunun malına el koymuş ve patrik III. Sahak ve Simbat Bagratuni'yi tutuklayarak Şam'da ikamete göndermişti. Ancak Simbat tekrar geri dönünce Müslümanlara karşı Doğu Roma'yla ittifaka karar verdi ve bu hususta tüm nakhararlara çağrı yaptı. Bu çağrıya cevap verip bir araya gelenler arasında Aşot'un oğlu Simbat, Simbat'ın kardeşi Aşot ve daha önce Müslümanlara yardımcı olmuş olan Teodoros Rshtunik'in oğlu Vart da yer almaktaydı. Doğu Roma'ya gitmek için Aras boyunca ilerleyip Akori'ye ulaşmak istiyorlardı ancak Nahçıvan'da bulanan Müslüman ordusu onları takibe başladı. Fakat sayıları çok olmasına rağmen soğuk iklime alışık olmayan Müslümanlar pek başarı gösteremedi. Buz tutmuş Aras Nehri'nin geçmek isterken buzun kırılmasıyla çok sayıda Müslüman asker nehre düşerek can verdi. Sağ kalan 3 yüz kadar asker ise 695-696 yılına doğru Sünik'e varıp buranın hatunu Shusan'a sığındılar. Simbat onları ısrarla öldürmek istese de Shusan buna müsaade etmemiş ve onları güvenli bir şekilde Halife Abdülmelik'e göndermişti. Halife de ona çeşitli hediyeler gönderip teşekkürlerini iletmişti. ${ }^{80}$

Bu yardımlaşma da Müslümanlarla Ermenilerin arasını düzeltecek gibi değildi. Çünkü zafer kazanan Simbat ele geçirdiği ganimetlerden çok sayıda at ve öldürdüklerinin burunlarını Doğu Roma imparatoruna gönderdi. Bu tutumu karşılıksız kalmadı ve imparator tarafından

Abdülmecîd Turhaynî), (Neşr: Muhammed Ali Beydun), Dârü'l-Kütübi'l-illmiyye, Beyrut 2004, s. 120; Koyuncu, "a.g.m.", s. 16-17.

${ }^{79}$ Ghewond, a.g.e., s. 20-21.

${ }^{80}$ Ghewond, a.g.e., s. 23-26; Yovhannēs, a.g.e., s. 107-108; Asolik, a.g.e., s. 155; Grousset, a.g.e., s. 297-298.

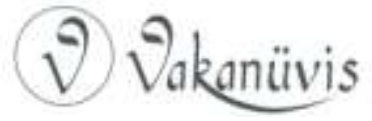


kuropalates ilan edilerek beklediği makamı almış oldu. Doğu Roma'dan tam destek alan Ermeniler Müslüman birliklere saldırmaya devam ettiler. Vaspuragan'da ilerlemiş olan Müslüman birlikler Rshtunik askerleri tarafından Kukank'ta bir kez daha yenilgiye uğradı. Kaçan 280 kadar Müslüman asker kiliseye sığınmış geriye kalanlar ise tamamen kılıçtan geçirilmişti. Kiliseye giremeyen Ermeniler burayı ateşe verip Müslümanları öldürmek istedi ancak Vaspuragan prensi Aşot buranın kutsal bir mekân olması nedeniyle yakılmasına müsaade etmedi. Müslümanlar anlaşma yolun denediyse de Ermeniler kesin olarak onları öldürmeye niyetliydi. Çaresiz olarak son bir kez daha çarpışmayı göze alan Müslümanlar dışarı çıkıp şehit olana kadar çarpıştılar. Komutanları ise Van Gölü'ne atıldı. Bundan sonra Müslümanların intikamından emin olan Simbat Tayk'ta Tuxar Kalesi'ne çekilip önlemler almaya başladı. ${ }^{81}$

$\mathrm{Bu}$ geliş̧meler Ermenilerin Müslümanlara karşı tavırlarının değiştiğini göstermektedir. İslam kaynaklarında da özellikle Abdülmelik'in halifeliğinin son dönemleri Ermenilerle ilişkilerin en bozuk olduğu dönemlerden biri olarak göze çarpmaktadır. H. 82 (701) yılında Muhammed b. Mervân'la yapılan barışın yine Ermeniler tarafından bozulması ve barış için bölgeye gönderilen Ebû Şeyh b. Abdullah'ın Ermeniler tarafından öldürülmesi Mervân'ı H. 82-85 (701704) yılları arasında Ermeniye gazaya devam etmeye mecbur bıraktı. ${ }^{82}$ Bu sıralarda Doğu Roma imparatoru Müslümanlar aleyhine gelişen faaliyetlere destek vermeye devam ediyordu. Bu iki güç Ermeniye başta olmak üzere, Gürcistan ve Abhazia hâkimiyeti için kıyasıya yarışıyordu. Bu amaçla Doğu Roma İmparatoru, II. Guaram'ı (684693)'te iberia kuropalatesi olarak tanıdı. Diğer taraftan Müslümanların Dvin genel valisine karşı çıkan Ermeni isyanlarını da destekledi. ${ }^{83}$

Beklendiği gibi Abdülmelik bu gelişmelerden sonra Muhammed'i çok sayıda askerle birlikte intikam için Ermenistan'a gazaya gönderdi.

\footnotetext{
${ }^{81}$ Ghewond, a.g.e., s. 26-27.

82 i̇bnü'l-Esîr, a.g.e., c. 4, s. 158, 178, 193; Ebû Abdillâh Şemsüddîn Muhammed b. Ahmed b. Osmân ez-Zehebî et-Türkmânî el-Fârikî ed-Dımaşkî, Târîhu'l-is/âm ve vefeyâtü'l-meşâhîr ve'l-a'lâm, (Neşr: Beşşâr Avvâd Ma'rûf), Beyrut 2003, c. 2, s. 913915; Nüveyrî, a.g.e., c. 21, s. 125; Ayrıca bkz. Movses, a.g.e., s. 130; Ghewond, a.g.e., s. 23.

${ }^{83}$ Subaşı, "Artvin", s. 2335.
}

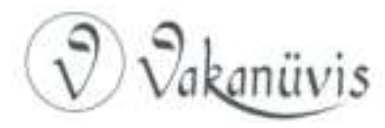


Ermeniler ise Patrik Şahak önderliğinde bir heyet hazırlayıp Müslümanlarla görüşmeye gönderdiler. Ancak patrik hedefine ulaşamadan 703 yılında Harran'da öldü. Haberi alan Muhammed hemen Harran'a gitti ve kendisi gelene kadar patriğin gömülmemesini emretti. Henüz gömülmemiş olan patriğin yanına gittiğinde Muhammed'e hitaben yazdığı mektup hala sağ elindeydi. Mektupta; "Halkım ve Ermeni nakhararlar sizden istediklerini dile getirmem için beni gönderdi. Ancak sizinle buluşup görüşmeyi başaramadım. Bizimle barış yaparsan yemin ederim insanlar vergi ödeyecek. Bizi öldürüp yağmalamaktan vazgeç, sana itaat edeceğiz. Sende buna karşılık bize dini serbestlik ver. Bizi bu hususta asla zorlama. Buna rağmen barış olmazsa topraklarımızı korumak için size karşı koyacağız". şeklinde bir yalvarış hitabı vardı. Bu duruma oldukça etkilenen Muhammed patriğe hitaben şöyle demişti; "Mektubunu okuyunca nasıl bilge bir insan olduğunu anladım. Sürüsünü gözeten cesur bir çoban gibi kılıcımın karşısına çıktın. Masumları öldürmemeye söz veriyorum." Bu mektup iki taraf arasındaki politikalara doğrudan yön vermiş oldu. Tıpkı mektupta geçtiği gibi Ermeniler vergi verip itaat etti, buna karşlık Müslümanlar da her hangi bir saldırıda bulunmadı. Hatta Vardanaket'te savaşanlara karşı bile her hangi bir intikam girişiminde bulunulmadı. Yine de her iki taraf da bir birlerine tam manasıyla güvenmiyor ve kuşkuyla bakıyordu. ${ }^{84}$

Yine de bu barış ortamı Doğu Roma'nın bölge politikalarını önlemek için Halife Abdülmelik'in bölgeye müdahalesine mani değildi. Abdülmelik b. Mervân şartlar gereği Doğu Roma'yla anlaşma yapmak zorunda kalarak Ermenistan'ı beraber yönetme kararı aldılar ve karar gereği elde edilen gelir aralarında paylaşılacaktı. Fakat Doğu Roma'nın baskısı dinmiyordu. Ermeniler, Doğu Roma'nın kendilerini zorla inanışlarına sokmaya çalışması üzerine Abdülmelik'ten yardım istemişlerdi. Ermeni Katolikos'u ilya, "Dünya Fatihi Emirü'l-mü'minin Abdülmelik" diye başlayan mektubunda Berde'de ikamet eden Albanya Katolikosu'ndan şikâyet etmekteydi. Albanya Katolikosu Doğu Roma'yla anlaşıp Ermenileri kendi itikatlarına sokmak istiyordu.

\footnotetext{
${ }^{84}$ Ghewond, a.g.e., s. 29-31; Yovhannēs, Patrik Şahak'la olan mektuplaşmalardan adı geçen Müslüman valinin Muhammed değil de Ukbe olduğunu kaydeder. Mektubun içeriği ve detaylı bilgi için bkz. Yovhannēs, a.g.e., s. 108.
}

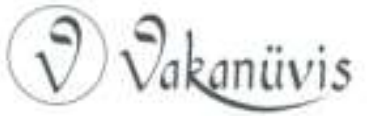


Halife'nin bu duruma müdahalesinin zaruri olduğu da beyan ediliyordu. Halife çağrıya, "Ermenilerin Allah Hadimi Katolikosu Ilya" şeklinde başlayan bir mektupla cevap verdi. Mektubunda adam gönderip meseleyi halledeceği belirtiliyordu. Sonuçta bu işin başı olan Nerses ve yardımcısı olan kadın cezalandırılarak Ermenilerin zorla Khalkedoncu olmaları önlenmişti. ${ }^{85}$

Abdülmelik'ten sonra hilafetin başına geçen Velid (H. 86-96/705715) döneminde Ermenilere karşı politikaların sertleştiği görülür. Bunun sebebi Ghewond'un belirtiğine göre Halife'nin Ermenilerin anlaşmalara uymadığını düşünmesiydi. Nakhararlar Tayk'a çekilip Doğu Roma yanlısı Simbat'tan yana tavır sergilemeye başlamıştı. Bunun üzerine Müslümanlar nakhararları ve süvarileri ondan ayırmak için hareke geçti. Bagratuniler ve nakhararları hedef alan Müslüman ilerleyişi karşısında Simbat bu kez de Doğu Roma desteğine başvurmaktan çekinmedi. Çağrıya cevap veren imparator yardımcı kuvvet gönderdi ve Simbat da askerleriyle bu birliğe dâhil olup Vanant'ta Drashpet'te karargâh kurdu. Grousset Velid'in Ermeni nakhararlarını ortadan kaldırmaya niyetlenmesinin sebebinin Doğu Roma müdahalesinin olabileceğini öne sürer. Diğer taraftan müttefik Doğu Roma-Ermeni birlikleri Muhammed ibn Mervân karşısında yenilmekten kurtulamadı. Savaşta yaklaşık 50 bin askerin öldüğü belirtilmektedir. H. 87 (705)'te Dvin'e giren Mervân Nahçıvan valisi Kasım'la birlikte nakhararlar üzerine kesin hâkimiyet sağlamak için birlikte hareket etti. ${ }^{86}$ Yine de belirtmek gerekir ki her ne kadar Müslümanların bölgeye yönelik siyasi tavırları şartlara göre değişse de dini serbestlik ve din adamlarına saygı politikalarında bariz değişiklikler görülmez. Daha önceki yöneticilerin dini liderlerle anlaşıp eman vermeleri belki de bölge halkını Müslümanlara yakınlaştıran en önemli etkendi. Muhammed'le patrik Şahak'ın ölüsü arasında geçen iltifat dolu konuşmalara benzer bir hadise de Filozofer Patrik Yovhannēs'le Halife Velid arasında geçmişti. Bilgeliğine hayran olduğu Yovhannēs'i Şam'daki sarayına davet eden Halife onu devlet erkânıyla beraber büyük bir törenle karşılayıp misafir etmişti. Yovhannēs hazırda

\footnotetext{
${ }^{85}$ Movses, a.g.e., s. 125.

${ }^{86}$ Ghewond, a.g.e., s. 31-32; Asolik, a.g.e., s. 155-156.
}

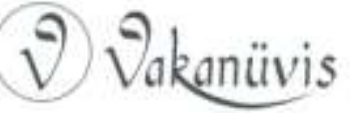


bulunanları hitabıyla etkilemeyi başarmış ve Halife'yi kendine hayran bırakmıştı. ${ }^{87}$

Bölgede hâkimiyeti tekrar Doğu Roma'dan alan Müslümanların bu aradaki sert politikası uzun sürmedi. Mervân'ın bölgede oluşturduğu hoşnutsuzluk Halife Velid'in dikkatini çekti ve vali değişikliğine karar verdi. Bölgeye önce Abdullah b. Hatim b. en-Numan b. Amr elBâhilî'nin onun ölümüyle de Abdullaziz b. Hâtim b. en-Numan'ın vali tayin edilmesi sert politikayı tersine çevirdi. Bu dönemde ilişkilerde başlayan yumuşamalar Ermenilerin başkenti Debîl'e yaradı. Bu şehir muhtemelen Hazar ve Doğu Roma akınlarına karşı bir hayli tahkim edilmiş, Neşevâ, Beylekan ve Berze'a gibi şehirler de imar edilmişti. Bölge artık Doğu Roma'yla birlikte Hazarlara karşı da bir üs halini aldı. ${ }^{88}$ Emeviler Mısır ve diğer yerlerde yaptığı gibi Berze'a'da da bölge hazinesini geniş ve güzel olan cuma mescidinde saklıyorlardı. Berze'a bu anlamda önemli bir mali merkez halini aldı. Yaklaşık iki asır sonraki İslam coğrafyacıları burada kurulan Kürkiy pazarının civarda önem kazanmış diğer bir pazar olan Külsere pazarına yakın büyüklükte olduğundan bahseder. Hatta haftanın günleri sayılırken pazarın kurulduğu gün Kürkiy olarak pazarın ismiyle anılır. Çevre yerlerden pek çok taciri bölgeye çeken bu pazar nedeniyle şehirde pek çok otel, han ve hamam gibi kervan sahiplerine hizmet eden müesseseler kurulmuştu. ${ }^{89}$ Sadece siyasi olarak değil mali olarak da pek çok gelişmeler yaşandı. Süleyman b. Abdülmelik (H. 96-99/714-717) döneminde Ermeniye'de gümüş paranın basılması Emevilerin bölgedeki ekonomi politikaları açısından mühimdir. Ön yüz çevresinde "Bismillâhi duribe hâze'd-dirhemi bi Ermeniyeti sene tisğa ve tisğine" (Allah'ın adıyla bu dirhem 99 yılında Ermeniye'de darb edilmiştir". yazan bu paranın diğer yüzünde diğer İslami sikkelerde olduğu gibi ayet-i kerimeler yer alır. 6 yıl sonra ise II. Yezid b. Abdülmelik (H. 101105/720-724) döneminde yine Emeviler adına bu kez Azerbaycan'da da gümüş para basılmıştır. Bu paranın ön yüz çevresinde "Bismillâhi duribe hâze'd-dirhemi bi Azerbaycan sene hamse ve mieti" (Allah'ın adıyla bu dirhem 105 yılında Azerbaycan'da darb edilmiştir". yazan

\footnotetext{
${ }^{87}$ Yovhannēs, a.g.e., s. 110.

${ }^{88}$ Belâzurî, a.g.e., s. 235-236; ỉbnü'l-Kesîr, a.g.e., c. 9, s. 298-299.

${ }^{89}$ i̇stahrî, a.g.e., s. 108-109; ỉbn Havkal, a.g.e., s. 338-339; Makdisî, a.g.e., s. 380.
}

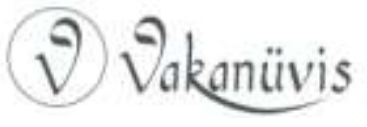


ibare mevcuttur. ${ }^{90}$ Berde, Derbent ve Şemahi'de de Müslümanlara ait darphaneler mevcuttu ve Arran'da basılan ilk sikke H. 89 (707-708) tarihli sikkedir. Basım yeri tam olarak tespit edilemese de Berde'den başka Şemkür, Kabele, Beylekan veya Gence'de basılmış olabileceği tahmin edilmektedir. Ayrıca Azerbaycan'da basılmış olan paranın da tam olarak yeri tespit edilememiş olmakla birlikte Erdebil veya Merağa'da basılmış olabileceği tahmin edilmektedir. Ayrıca Gence'de de H. 94 (712-713) yılında dirhem basıldığı görülmektedir. ${ }^{91}$

Bu ticari gelişmelerin yanı sıra Ermeni kaynaklarının sağır olmasına karşın çok dikkatli ve kurnaz ayrıca yumuşak kalpli bir yönetici olduğunu belirttiği yeni vali Bâhilî, Simbat'ın da yer aldığı sürgündeki nakhararları geri çağırarak onlara eski mülklerini iade etme sözü verdi. Müslümanlardan güvence alan nakhararlar bulundukları yerlerdeki kiliselerin hazinelerini alıp yurtlarına geri döndüler. Bu tavırlarına Doğu Roma'nın tepkisi gecikmedi. Bunu duyan imparator kilise liderleri, metropolit ve başpiskoposlarla bir araya gelip kendilerinden kopan Ermeni yöneticileri aforoz ettiklerini açıkladılar. ${ }^{92}$

$\mathrm{Bu}$ tavırlar Müslümanların ilk dönem politikalarına dönme gereksinimi duyduklarını da ortaya koymaktadır. Benzer bir af ve yumuşak politika da Ömer b. Abdülaziz'in (H. 99-101/717-720) dönemine rastlar. Hoşgörü politikasının daha da belirginleştiği bu dönemde genel af çıkaran Halife Ermenilere yurtlarına dönme imkânı sağladı. Ghewond bu sebeple onun diğer halifelerden daha soylu olduğunu belirtir. ${ }^{93}$

Ancak Doğu Roma'nın bölgeye saldırıları henüz bitmemişti. Yezid b. Abdülmelik'in ilk yıllarında, Cezîre valisi Ömer ibn Hübeyre H. 102 (720) yılında Ermenistan'daki Doğu Roma birliklerine saldırarak onları mağlup etmiş ve 700 kadarını esir almıştı. ${ }^{94}$ Bölge bir yandan Doğu

\footnotetext{
90 ibrahim Artuk, Cevriye Artuk, istanbul Arkeoloji Müzeleri Teşhirindeki İslâmî Sikkeler Kataloğu, c. 1, Milli Eğitim Bakanlığı Eski Eserler ve Müzeler Genel Müdürlüğü Yayınları, Seri: III, No: 7, İstanbul 1971, s. 22, 27.

${ }^{91}$ Büniyatov, a.g.e., s. 195, 205.

${ }^{92}$ Ghewond, a.g.e., s. 35-36; Asolik, a.g.e., s. 157.

${ }^{93}$ Ghewond, a.g.e., s. 99; İslam kaynakları da Halife Ömer b Abdülaziz'den övgüyle bahseder. İbnü'l-Esîr, a.g.e., c. 4, s. 309-315.

${ }^{94}$ Taberî, a.g.e., c. 6, s. 616; Ya'kūbî, a.g.e., c. 2, s. 243; ỉbnü'l-Esîr, a.g.e., c. 4, s. 338; Ebü'l Ferec Cemâlüddîn Abdurrahmân b. Alî b. Muhammed el-Bağdâdî íbnü’l-Cevzî, el-
}

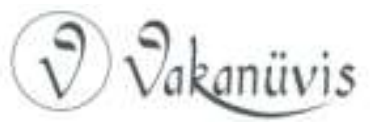


Roma baskısına diğer yandan da Hazar akınlarına maruz kalmaktaydı. $\mathrm{Bu}$ da Müslümanların Güney Kafkasya politikalarını yeniden gözden geçirip değiştirmelerine neden oldu. Aslında bu politika değişikliğinin sebebi çok açıktı. Müslümanları bölgede tehdit eden yeni bir aktör daha çıkmıştı ki bu da uzun yıllar mücadelenin devam edeceği Hazarlardı. Halifeliğin kuzey sınırlarındaki Hazar tehlikesi kolay savuşturulacak gibi gözükmüyor ve bölge valileri ardı ardına değiştiriliyordu. Bölge valiliği H. 104-106 (722-725) ve H. 111 (729-730) yıllarında Cerrah b. Abdullah el-Hakemî ile Mesleme b. Abdülmelik arasında sık sık değişti. H. 109-110 (727-728) Hazarlar karşısında istenilen başarıyı gösteremeyen Mesleme b. Abdülmelik'in yerine atanan Cerrah b. Abdullah, Merc-i Erdebil'de ağır bir yenilgi alarak beraberindekilerle birlikte şehit oldu. Hazarlar ise bu galibiyetleriyle Musul'a kadar ilerlediler. Tekrar vali olan Mesleme b. Abdülmelik komutanı Sa'id ibn Amr el-Haraşî ile birlikte H. 112 (730-731)'de Hazarlara karşı etkili mücadeleler verdi ve bin kadar Hazarlı ailenin bulunduğu Bâb'ül-Ebvâb şehrini fethederek Şam halkından maaşlı 24 bin kişiyi buraya yerleştirdi. Fakat bu da Hazarları durdurmaya yetmedi. ${ }^{95}$ Hazarlarla olan bu mücadelenin en önemli nedenini de yine

Muntazam fî târîhi'l-mülûk ve'l-ümem, c. 7, (Neşr: Muhammed Abdülkâdir Atâ, Mustafa Abdülkâdir Atâ), Beyrut 1992, 1995, s. 81; Nüveyrî, a.g.e., c. 21, s. 229.

95 Emevilerin Hazarlarla mücadeleleri hakkında bkz. Belâzurî, a.g.e., s. 237-240; Ya'kūbî, Hişam tarafından H. 107 (725-726)'de Ermeniye ve Azerbaycan'a gönderilen Mesleme b. Abdülmelik'in fetihlerini sayarken onun Azerbaycan topraklarının sonu olan Versân'a kadar ilerlediğini ve Hazar melikiyle savaştığını belirtir. Ya'kūbî, a.g.e., c. 2, s. 245-246; Ayrıca bkz. İbnü'l-Esîr, a.g.e., c. 4, s. 381-383; íbnü’l-Kesîr, a.g.e., c. 9, 418; Ghewond, a.g.e., s. 18-19; Movses, a.g.e., s. 131; Mehmet Çog, "Emeviler ve Abbasiler Dönemi Hazar-Arap Iliş̧kileri”, Turkish Studies, c. 2, Sa. 2, 2007, s. 154-155; Valiliğinin ilk yıllarında başarılı fetihler gerçekleştiren Cerrah b. Abdullah H. 104 (722723) yılında Hazarları mağlup ederek Belencer'e varmış ve kaleyi ele geçirmişti. Buradan her bir süvari için 300 dinar olmak üzere toplamda 30 bin dinardan fazla paranın yanı sıra epeyce ganimet elde etmişti. Belencer melikinin ailesi ve çocuklarını da ele geçiren Cerrah $b$. Abdullah 40 bin evlik Türk topluluğunun bulunduğu Vebender'e ilerleyip burayı haraca bağlayarak anlaşma yaptı. İbnü'l-Esîr, a.g.e., c. 4, s. 344-345; Ayrıca bkz. Kitâbu'I-Uyûn ve'l-Hadâik fi Ahbâri'l-Hakâik, c. 3, (Neşr: Ömer esSaîdî), Dımaşk 1972, s. 75; Nüveyrî, a.g.e., c. 21, s. 231-233; Bu başarılarını devam ettiremeyince Hişam H. 107 (722-723) yılında onu bölge valiliğinden alarak yerine Mesleme b. Abdülmelik'i getirdi. Ebü'l-Felâh Abdülhay b. Ahmed b. Muhammed esSâlihî el-Hanbelî İbnü'l-i̇mâd, Şezerâtü'z-zeheb fi Ahbâri men Zeheb, c. 2, (Neşr: Abdülkâdir el-Arnaût, Mahmûd el-Arnaût), Beyrut 1986-1995, s. 43; Ayrıca bkz. Zehebî,

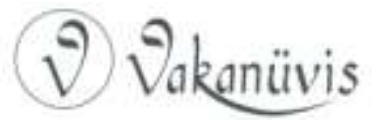


Doğu Roma'yla olan ittifaklarıydı. Daha önce Ermeniler vasıtasıyla bölgeyi elinde tutmak isteyen Doğu Roma bu kez Müslümanların düşmanı olan Hazarları desteklemekle politikasın devam ettirmeye çalıştı. ${ }^{96}$

Hazarlarla mücadelede tecrübenin gerektiğine inanan Halife Hişam b. Abdülmelik H. 114 (732-733) yılında amcasının oğlu ve daha önce Hazarlara karşı Mesleme'nin ordusunda görev yapmış olan Mervân b. Muhammed b. Mervân'ı Cezîre, Azerbaycan, Bâb ve Ermeniye valiliğine getirdi. ${ }^{97}$ Ermenistan başkenti Dvin'e gelen Mervân b. Muhammed kendisiyle tanışmak için hazır bulunan Ermeni nakhararlar tarafından karşılandı. Mervân b. Muhammed onlara çok barış̧̧ıl bir konuşma yaptıktan sonra Bagratunilerden Vasak'ın oğlu Aşot'u çağırıp onu Halife adına Ermenistan yönetici yaptı ve patricus ünvanı vererek onurlandırdı. Ancak bu durum Simbat'ın oğulları tarafından hiç de hoş karşılanmadı. Bu hoşnutsuzluk Mervân'ın kulağına gidince Mamigonyanlı Grigor ve Davit tutuklanarak Halife Hişam'ın yanına Şam'a gönderildi. Halife ise onları Yemen'e sürgüne gönderdi. Mamigonyanlılar kendilerine haksızlık edildiğini düşünmekteydi. Bundan sonra Hazar akınlarının durdurulmasında Müslümanlar Ermeni

a.g.e., c. 3, s. 9, 11; Ancak H. 111 (729-730) yılında Türklerin Azerbaycan'a ilerlemeleri Cerrah b. Abdullah'ın tekrar bölgeye vali atanmasına neden oldu. Türkler bu ilerlemede Haris b. Ömer tarafından yenilgiye uğratıldılar. H. 112 (730-731) yılında Hazarlar bu kez Erdebil'e kadar ilerlediler ve Cerrah b. Abdullah el-Hakemî ile savaştılar. Ancak Cerrah b. Abdullah el-Hakemî, el-Lan taraflarından gelen Türkler tarafından öldürülünce yerine Muhammed b. Mervân bölge valisi oldu. Taberî, a.g.e., c. 7, s. 14, 67, 70; Ya'kūbî, a.g.e., c. 2, s. 260; İbnü'l-Esîr, a.g.e., c. 4, s. 379; Hazarlarla olan mücadeleler için ayrıca bkz. İbnü'l-Kesîr, a.g.e., c. 9, s. 418, 495-497; Azerbaycan ve Ermeniye valilerinin listesi için bkz. E. De Zambaur, Manuel de Genealogie et de Chronologie Pour L'Histoire de L'islam, Hanovre 1927, s. 177-178.

${ }^{96}$ Detaylı bilgi için bkz. Ostrogorsky, a.g.e., s. 146.

${ }^{97}$ Taberî, a.g.e., c. 7, s. 90, 91, 108; Ya'kūbî, a.g.e., c. 2, s. 246; ỉbnü'l-Esîr, a.g.e., c. 4, s. 395-396, 409; íbnü'l-Kesîr, a.g.e., c. 10, s. 85-87; íbnü'l-Cevzî, a.g.e., c. 7, s. 159; Kitâbu'I-Uyûn, c. 3, s. 90; Hilafet merkezi bundan sonra Abbasiler döneminde de bölgeye gönderdiği adamların iyi yetişmiş olmasına dikkat etti. H. 132 (749-750) yılında Abbasilerden Cezîre bölgesine ilaveten bölgeye gönderilen ilk vali Halife es-Seffah Ebû'l-Abbas'ın oğlu Ebû Cafer el-Mansur'un olması bu anlamda mühimdir. Detaylı bilgi için bkz. İbnü'l-Esîr, a.g.e., c. 4, s. 603; Zehebî, a.g.e., c. 3, s. 585; Taberî, a.g.e., c. 7, s. 447; ỉbnü'l-Cevzî, a.g.e., c. 7, s. 311; Kitâbu'I-Uyûn, c. 3, s. 208; Ghewond, a.g.e., s. 127.

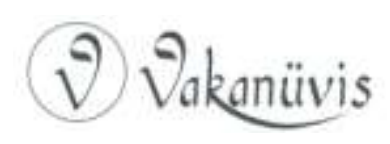


nakhararları olabildiğince destekledi. Bu karşılıklı olarak Ermeni feodallerinin de işine geliyordu. Bir taraftan Halife'ye bağlılık gösteriyorlar diğer taraftan Halife'den istedikleri yardımı alıyorlardı. Bu bağlamda Aşot Bagratuni'nin hilafet merkezi Şam'ı ziyareti Hazarlara karşı ikili ilişkilerde büyük önem taşır. Müslüman ordusundaki Ermeni askerlerin maaşlarının karşılanması hususu üzerine kurulan ittifak Müslümanların bir hayli işine yaradı. Aşot bu görüşmede ayrıca Ermeni askerlerinin kalan maaşlarının da ödenmesini sağladı. Aşot'un bilgeliğinden memnun olan Halife Hişam onun isteklerini yerine getirdi ve önceki yıldan kalan 100 bin gümüş dirhemin ödenmesini emretti. Bundan sonraki dönemde süvarilerin maaşları aksatılmadan ödendi. ${ }^{98}$ Hazar tehdidi arttıkça Müslümanların Ermenilerle ilişkileri Hazar akınlarını durdurmaya yönelik oldu. Bu sebeple H. 117 (735-736) yılında Mervân b. Muhammed Ermeniye'ye iki ordu sevk etmiş bunlardan ilki Ellan bölgesinde 3 kale fethederken diğeri Tumanşâh'a kadar ilerlemişti. ${ }^{99}$ Ermeniye'de fetihlere ara vermeyen Mervân b. Muhammed hemen akabinde H. 118 (736)'da Vernis'in topraklarına girip onu Hazar topraklarına kadar kovaladı. Hazarlara sığınan Vernis Mervân b. Muhammed tarafından yakalanıp öldürülmekten kurtulamadı. ${ }^{100}$ H. 119 (737) yılında ise Kafkasya ve Bâbü'l-Ebvâb arasındaki Hazarları püskürten müttefik Müslüman-Ermeni birlikleri Hazarların başkenti Belencer'e kadar girerek pek çok ganimet elde etmeyi başardı. Berde şehrine getirilen bu ganimetlerden Aşot Bagratuni'yle birlikte diğer nakhararlar da hisselerini aldılar. ${ }^{101}$

Emevilerin son dönemlerinde iç politikada yaşadıkları krizler Ermeni yöneticilerini özerklik beklentisiyle bir hayli umutlandırmış ve Mervân b. Muhammed'in bölgeden ayrılmasıyla birlikte Mamigonyanlardan Grigor ve Davit kaçarak Ermenistan'a varmışlardı. Ghewond'un belirttiğine göre Velid onları serbest bırakmış ancak onlar Suriye'ye ulaşamadan tekrar yakalanmışlardı. iç kargaşanın devam ettiği bir sırada tekrar kaçmayı başarmışlardı. Ancak Ermensitan'da Mamigonyanlar yerine güçlenen Bagratuniler onların başına buyruk hareket etmelerine müsaade etmiyordu. Van (Vaspuragan) ve

\footnotetext{
${ }^{98}$ Ghewond, a.g.e., s. 112-114.

${ }^{99}$ Taberî, a.g.e., c. 7, s. 99; İbnü'l-Esîr, a.g.e., c. 4, s. 402.

100 ibnü'l-Esîr, a.g.e., c. 4, s. 412.

${ }^{101}$ Ghewond, a.g.e., s. 114.
}

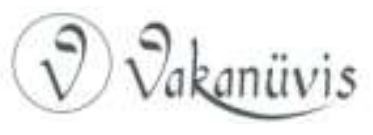


dolaylarında Bagratunilerden Aşot'la olan mücadeleleri nedeniyle kendilerine karşı bir cephe oluşmuştu. Bununla birlikte zorla gelir toplamak istemeleri de halkın hiç hoşuna gitmemişti. Emevi valisi İshak ibn Müslim bu durumu engellemek için bir takım girişimlerde bulundu fakat nakhararlar arasındaki kavgayı sonlandırmada başarılı olamadı. Hatta neredeyse Grigor ve Davit kardeşler Aşot'u yakalayıp öldüreceklerdi. Aşot durumu Halife II. Mervân'a bildirip onlara karşı destek istemeye gittiği sırada Grigor Mamigonyan onun yerine geçerek Ermeni kuvvetlerini kendi emrine vermesi için Emevi valisini ikna etti. $\mathrm{Bu}$ hamle işleri daha da karmaşık ve zor bir duruma soktu. Fakat Aşot ve adamları hilafetteki iç karışıklıkta yaklaşık 15 bin seçkin askeriyle II. Mervân'a yardımda bulunmuştu. Bu duruma çok sevinen II. Mervân onun bu yardımını karşılıksız bırakmadı. Kısa süre sonra Aşot, David Mamigonyan'ı yakalayarak Halife'den büyük saygı görerek tekrar Ermenistan yöneticisi olarak bölgeye dönmüştü. Ancak Grigor Mamigonyan kardeşinin öldürülmesi nedeniyle Aşot'a karşı bir hayli kinliydi ve sadece göstermelik olarak ona itaat ediyor intikam için fırsat kolluyordu. ${ }^{102}$

Müslümanlar Bagratunileri destekleyerek iki büyük yönetici aile arasındaki dengeyi korumak istemişlerdi. Birinin diğerine üstünlük kurması aynı zamanda hilafete de karşı gelmesinin yolunu açabilmekteydi. Fakat ne Emeviler'de ne de Ermeni feodaller arasında iç çekişmelerin ardı arkası kesilmedi. Grigor Mamigonyan Aşot'u görevden uzaklaştırmak fikrini öne sürdü. Aşot'un yanındaki nakhararlar ise Aşot'u Müslümanlara başkaldırmaya ikna etmeye çalışıyordu. Aşot ise birliklerinin çok az olduğunu öne sürerek böyle bir girişimin sadece felaket getireceğini belirtiyordu. Bundan vazgeçip şu anda olduğu gibi vergi vererek, sahip oldukları mülklerin, bağların ve çiftliklerin elde tutulması gerektiğini savunuyordu. Ancak nakhararlar buna karşı gelerek askerlerinin kendisiyle birlikte olmayacağını ve ülkelerinin durumuna göz yummamaları gerektiğini söylediler. Prens Aşot isteksiz de olsa Grigor ve diğer nakhararlarla birleşmeyi kabul etti. Sonra hep beraber ittifaklarına bağıı kalmak üzere kutsal haçın önünde

${ }^{102}$ Ghewond, a.g.e., s. 118-121; Mervân b. Muhammed'in H. 120 (737-738) yılında da Ermeniye ve Azerbaycan âmili olduğu görülmektedir. Bkz. Taberî, a.g.e., c. 7, s. 159; İbnü'l-Esîr, a.g.e., c. 4, s. 434.

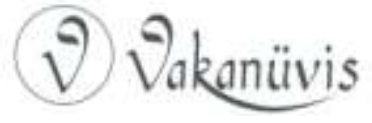


yemin ettiler. ${ }^{103} \mathrm{Bu}$ genel isyan girişiminin oluşturulduğu güvensiz ortam bazı nakhararları aile ve mallarıyla birlikte Tayk civarına çekilmeye zorladı. Burası Doğu Roma sınırına yakın olması nedeniyle özenle seçilmişti. V. Konstantinos'un yardımı buraya kolayca ulaşabilirdi. Baştan beri isteksiz olan Aşot bu birlikten ayrılıp bazı lordlarla birlikte Bagravan'daki Hazr köyüne gitti. Bu arada Grigor Mamigonyan Aşot'u yakalayıp gözlerini oyarak öldürülen kardeşi David'in intikamını almış oldu. Bu feodal kavgalar Ermenistan'a hiçbir yarar getirmedi. Ghewond'un belirttiğine göre görkemli taç başlarından düşmüş ve ülke harap olmuştu. Grigor ise Karin şehrine gelip zafer mesajları yayınlasa da orada hastalanarak öldü. Yerine 750 yılında kardeşi Muşeğ prens oldu. ${ }^{104}$ Devam eden bu kavgalar ve iki aile arasındaki siyasi rekabet Abbasilerin de bölge politikasına yön veren baş etmen olacağını gösteriyordu.

Ermeni soylularının daha önce Doğu Roma-Sâsânî savaşlarında olduğu gibi Doğu Roma-Müslüman savaşlarında da müttefik olarak en iyi tarafı seçmek zorundaydılar ancak bu seçimde her zaman akıllıca davranmamışlardı ve yanılgıya düşmüşlerdi. Müslümanlara karşı başlatılan isyan girişimleri onların rehin düşmesine veya mallarının elinden alınmasına neden oldu. Yine de Müslümanların vergi politikası Ermeni sosyal ve ekonomik yaşamında büyük değişikliklere neden oldu. Ermeniler ilk zamanlar kendilerine yetecek kadar üretim yaparken şimdi tanıdıkları yeni pazarlar ve müşterilere ürün yetiştirmek için hem ziraat hem de ticaret mallarının üretimini çoğalttı. Ermeni ticareti artık dışa açılmış ve Müslümanların sunduğu imkânlardan azami derecede yararlanmayı bilmişti. Bu durum Kafkasya'da güçlü ve zengin bir şehir yaşamı meydana getirirken daha önce var olmayan, Ani, Kars, Bitlis, Ahlat, Ardanuç, Beylekan, Gence, Şemkür, Dvin, Tiflis, Berde'a, Hançivan ve Erzurum gibi yeni ticaret ve yaşam merkezlerinin meydana gelmesine zemin hazırladı. ${ }^{105} 10$. yüzyılın İslam coğrafyacıları bölgenin yerleşim yerlerinden bahsederken bölgeye dışarıdan gelen tacirlerden, ticaret merkezlerinden ve yollarından sı sık bahsetmektedirler.

\footnotetext{
${ }^{103}$ Ghewond, a.g.e., s. 121-122.

${ }^{104}$ Ghewond, a.g.e., s. $122-123$.

${ }^{105}$ Hewsen, Armenia, s. 105.
}

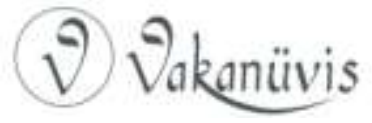


Müslümanların bölgede tam hâkimiyeti sağlamasından sonra gerek ziraat gerekse ticaret açısından bölgede büyük gelişmeler sağlandı. Her yerleşim yerinde camilerin yanındaki pazarların yanı sıra zengin ürün çeşitliliğiyle çok uzak yerlerden tacirleri bölgeye çeken Kürkiy ve Külsere pazarları bölgenin adeta ticaret merkezleri arasında yerini almıştı. Bununla birlikte sadece Ermeniye'ye mahsus bazı ürünler dünyanın çeşitli yerlerine ihraç edilmiş bu anlamda bölgenin adı pek çok yerde duyulmuştu. ${ }^{106}$ Araştırıcılar daha önce sürekli savaşlar ve feodal beyler arasındaki çekişmeler nedeniyle bir hayli tahrip olan Ermenistan'ın ilk Müslüman hâkimiyetiyle birlikte milli ve edebi olarak gelişme çağına girdiğini belirtmekte ve Müslüman fetihlerin bölge ekonomisinin yanı sıra bölge halkı ve kültürü için de ne denli öneme sahip olduğunu ortaya koymaktadır. ${ }^{107}$

\section{Sonuç}

Müslümanların Ermenistan'a yönelik bu ilk fetih hareketleri Ermenistan'ı ele geçirmekten ziyade Doğu Roma'yla yapılan Yermük Savaşı'ndan (636) kaçan Doğu Roma birliklerini takip amaçlıydı. Diğer takip ise Sâsânî birliklerinde yer almış olan Ermenilere yönelikti. Bu takip ilk olarak Azerbaycan'da gerçekleşmişti. Sâsânî ve Doğu Roma birliklerinde yer almış olan Ermenilerin dağlık memleketlerindeki soydaşlarının yanına kaçmaları Müslümanlar için cazip olmasa da onları bu dağlık ve karasal bölgeye akınlar düzenlemeye sevk etmişti. Ermeni birliklerinin tekrar tehlikeli bir şekilde organize olmaları ve Müslümanlar aleyhine Doğu Roma ile ittifak yapmaları bu şekilde önlenecekti. Sâsânîlerden alınan bölgenin sınır güvenliğini sağlamak Güney Kafkasya'yı da kontrol altında tutmakla mümkün olacaktı.

Öte yandan bölgeye gönderilen valilerin hilafetin varisleri olması veya halifelerin yakın adamlarından seçiliyor olması dahi İslam kaynaklarının bölgeye ilgisini çok fazla arttırmış gibi gözükmüyor. Abbasilerin ilk bölge valisi bile ilk Abbasi halifesi Seffah'ın yerine

106 Detaylı bilgi için bkz. İstahrî, a.g.e., s. 108-114; ibn Havkal, a.g.e., s. 301-355; Makdisî, a.g.e., s. 373-384; Hudûdü'l-Âlem, s. 101-104.

107 Tezcan, Klasik ve Ortaçağ Dönemlerinde Karadeniz ve Kafkasya, Serander Yayınları, Trabzon 2012, s. 255.

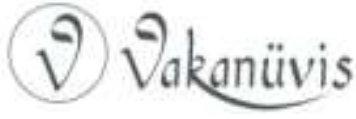


geçecek oğlu Mansur'du. Bu anlamda hilafet merkezinin bölgeye yeterince önem verdiği anlaşılmaktadır ancak buna rağmen İslam kaynaklarının bölgeye yönelik kayıtları öncekilerden aktarılan dağınık rivayetlerden olmuştur. Aslında bu nokta Müslüman idarecilerin bölgeye bakışını da özetlemektedir. Fethedilen yerlerde genelde İslamiyet'in yaygınlaştırılması amacı güdülmüş olmasına rağmen kilise kurallarına ve dinlerine sıkı sıkıya bağlı kalan Ermenilere İslamiyet'i kabul ettirmenin zorluğu Müslümanlar tarafından benimsenmiş olmalı ki burayı din serbestliği de dâhil olmak üzere bazı anlaşmalarla ve merkezden atanan valilerle elde tutmak daha büyük öncelik haline gelmişti. Bununla birlikte Ermenilerin dini taassubunu hiçe sayan Doğu Roma bu ayrıntıyı gözünden kaçırmış veya önemsememişti. Öyle ki kendi inançlarını dayatmaları Ermenileri Müslümanlara daha da yakınlaştırırken kendi dinlerinin dışını çıkmak bir yana mezheplerinin dışına dahi çıkmayacaklarını ispatlamış oldular. Yine de Ermeniler üzerinde kurulacak en azından siyasi hâkimiyet Ermenistan'ın stratejik konumunun bir gereğiydi. Ayrıca dağlık arazi veya Müslüman tüccarların ürünlerine ilgi duyacak yeterli pazarların olmayışı da bölgenin Müslümanlar açısından cazibesini azaltmaktaydı. Bununla birlikte bu eğilim fetihlerden yaklaşık bir iki asır sonra değişecek, yaşanan siyasal gelişmeler bölge zenginliğini başlı başına Müslüman veya gayr-ı Müslüm tüccarın ilgi odağı haline getirecekti.

\section{Kaynakça}

Abû'I-Farac, Gregory, Abû'I-Farac Tarihi, c. I-II, (Süryanice'den İngilizceye Çeviren: Ernest A. Wallis Budge), (Türkçeye Çeviren: Ömer Rıza Doğrul), TTK, Ankara 1999.

Artuk, İbrahim-ARTUK, Cevriye, istanbul Arkeoloji Müzeleri Teşhirindeki islâmî Sikkeler Kataloğu, c. 1, Milli Eğitim Bakanlığı Eski Eserler ve Müzeler Genel Müdürlüğü Yayınları, Seri: III, No: 7, İstanbul 1971.

Asolık, Açogh'ıg de Daron (Asolik), Histoire Universelle Par Etienne Açogh'ig de Daron Traduite de l'armênien et Annotêe, Livre III, (Neşr: E. Dulaurier), Paris 1883.

Belâzurî, Ahmed b. Yahyâ el-Belâzurî, Fütûhu'l Büldân (Ülkelerin Fetihleri), (Çev: Mustafa Fayda), Siyer Yayınları, İstanbul 2013.

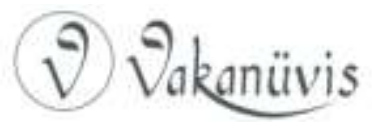


Bournoutian, George A., A History of the Armenian People Volume I: PreHistory to 1500 A. D., California 1993.

Büniyatov, Ziya Musa, Azerbaycan VII-IX Esrlerde, Bakü 2007.

Büniyatov, Ziya Musa, “Azerbaycan” DiA, c. 4, 1991, s. 317-322.

Çog, Mehmet, "Emeviler ve Abbasiler Dönemi Hazar-Arap ilişkileri", Turkish Studies, c. 2, Sa. 2, 2007, s. 150-160.

Fayda, Mustafa, "Atâ", DiA, c. 4, 1991, s. 33-34.

Ghewond, Ghewond's History, (Translated: Robert Bedrosian), Sources of the Armenian Tradition, Long Branch, N. J., 2006.

Grousset, René, Başlangıçtan 1071'e Ermenilerin Tarihi, (Çev: Sosi Dolanoğlu), Aras Yayıncılık, İstanbul 2006.

Gürcistan Tarihi (Eski Çağlardan 1212 Yılına Kadar), (Gürcüceden Çev: Marie Féliceté Brosset), (Çev: Hrand D. Andreasyan), (Notlar ve Yayına Hazırlayan: Erdoğan Merçil), TTK, Ankara 2003.

Hamevî, Şihâbiddîn Ebi Abdillâh Yâkût b. Abdillâh el-Hamevî er-Rûmî elBağdâdî, Mu'cemü'l-Büldân, c. 1-5, Beyrut 1977.

Hewsen, Robert H., The Geography of Ananias of Širak (AŠXARHAC'OYC'), Wiesbaden 1992.

Hewsen, Robert H., Armenia A Historical Atlas, The University of Chicago Press, London 2001.

Hudûdü'l-Âlem Mine'l-Meşrik Ile'l-Magrib, (Neşr: Vladimir Minorsky), (Çev: Abdullah Duman, Murat Ağarı), İstanbul 2008.

İbn Havkal, Ebü'l-Kâsım İbn Havkal en-Nasibî, Sûretü'l-arz, (Neşr: M. J. De Goeje), (Bibliotheca Geographorum Arabicorum c. II), Leyden 1967.

İbnü'l-Cevzî, Ebü'l Ferec Cemâlüddîn Abdurrahmân b. Alî b. Muhammed el-Bağdâdî ibnü'l-Cevzî, el-Muntazam fî târîhi'l-mülûk ve'l-ümem, c. 1-19, (Neşr: Muhammed Abdülkâdir Atâ, Mustafa Abdülkâdir Atâ), Beyrut 1992, 1995.

İbnü'l-Esîr, Ebu'l-Fida İbnü'l-Esîr, Ali b. Muhammed b. Abdilkerîm el-Cezerî eş-Şeybânî, el-Kâmil fi't-Târîh, (İslâm Tarihi), c. 1-10, (Tecüme Heyeti: Ahmet Ağırakça, Beşir Eryarsoy, Zülfikar Tüccar, Abdülkerim Özaydın, Yunus Apaydın, Abdullah Köşe), Ocak Yayıncılık, İstanbul 2016.

İbnü'l-İmâd, Ebü'l-Felâh Abdülhay b. Ahmed b. Muhammed es-Sâlihî elHanbelî ibnü'l-i̇mâd, Şezerâtü'z-zeheb fi Ahbâri men Zeheb, c. 1-10, (Neşr: Abdülkâdir el-Arnaût, Mahmûd el-Arnaût), Beyrut 1986-1995.

İbnü'l-Kesîr, Ebü'l-Fidâ' İmâdüddîn İsmâîl b. Şihâbiddîn Ömer b. Kesîr b. Dav' b. Kesîr el-Kaysî el-Kureşî el-Busrâvî ed-Dımaşkî eş-Şâfiî (İbnü'l-Kesîr), elBidâye ve'n-nihâye, c. 1-14, (Çev: Mehmet Keskin), Çağrı Yayınları, İstanbul 1985.

İpek, Ali, "Sâcoğulları”, DiA, c. 35, 2008, s. 364-366. 
İpek, Ali, Ortaçağ Müslüman Idarelerde Ermeniler-Makaleler-, Atatürk Üniversitesi Yayınları, Erzurum 2015.

İstahrî, Ebu i̇shâk İbrâhim b. Muhammed el-İstahrî el-Fârisî, el-Mesâlik ve'lMemâlik, (Tahkik: Muhammed Câbir Abdulâl el-Hînî), 1961.

Jones, A. H. M., The Cities of the Eastern Roman Provinces, Oxford 1971.

Kaegı, Walter E., Bizans ve Ilk Islam Fetihleri, (Çev: Mehmet Özay), İstanbul 2000.

Kartlis Tskhovreba (History of Georgia), (Translated: Dmitri Gamq'relidze, Medea Abashidze, Arrian Chant'uria), (Edit: Roin Met'reveli, Stephen Jones), Georgian National Academy of Sciences, Artanuji Publishing, Tbilisi 2014.

Kitâbu'I-Uyûn ve'I-Hadâik fi Ahbâri'l-Hakâik, c. 3, (Neşr: Ömer es-Saîdî), Dımaşk 1972.

Koyuncu, Mevlüt, “Müslüman Arapların İslam'ın Illk Fetihleri Döneminde İrminiyye İle Olan Münasebetleri", Tarihte Türkler ve Ermeniler (Ortaçağ), c. 2, TTK, Ankara 2014, s. 9-20.

Lang, David Marshall, Eski Halk ve Ülkeler, Gürcüler, (Çev: Neşenur Domaniç), İstanbul 1997.

Makdisî, Şemsüddîn Muhammed b. Ahmed b. Ebî Bekr el-Bennâ el-Makdisî eş-Şâmî el-Beşşârî, Ahsenü't-tekâsîm fî ma'rifeti'l-ekâlîm, (Neşr: M. J. De Goeje), Brill 1877.

Mehmetov, İsmail, Türk Kafkası'nda Siyasi ve Etnik Yapı, Eski Çağlardan Günümüze Azerbaycan Tarihi, (Eklemeler, Notlandırma ve Düzenlemelerle Türkçe Yayına Hazırlayanlar: Ekber N. Necef, Şamil Necefov), Ötüken Neşriyat, istanbul 2009.

Movses, Dasxurants'i's, History of the Aghuans, (Translated: Robert Bedrosian).

Muhammedoğlu, Aliyev Salih, "Kafkasya (Tarih)", DiA, c. 24, 2001, s. 158160.

Norwich, John Julius, Bizans Erken Dönem (MS 323-802), c. 1, (Çev: Hamide Koyukan), ìstanbul 2013.

Nüveyrî, Ebü'l-Abbâs Şihâbüddîn Ahmed b. Abdilvehhâb b. Muhammed eBekrî et-Teymî el-Kureyşî en-Nüveyrî, Nihâyetü'l-ereb fí Fünûni'l-edeb, c. 1-32, (Tahkik: Abdülmecîd Turhaynî), (Neşr: Muhammed Ali Beydun), Dârü'lKütübi'l-ilmiyye, Beyrut 2004.

Ostrogorsky, Georg, Bizans Devleti Tarihi, (Çev: Fikret Işıltan), TTK, Ankara 2006.

Samouel D’ani, Tables Chronologiques, (Neşr: Marie Félicité Brosset), Collection D'Historiens Armeniens, S-Petersbourg, 1876.

Schiltberger, Johannes, Türkler ve Tatarlar Arasında (1394-1427), (Çev: Turgut Akpınar), i̇stanbul 1997.

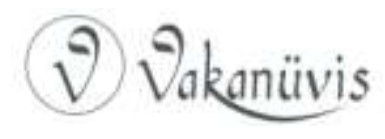


Sebeos, History, (Translated: Robert Bedrosian), Sources of the Armenian Tradition, New York 1985.

Subaşı, Ömer, "Arap Akınlarına Kadar Artvin ve Çevresi", A. Ü. Türkiyat Araştırmaları Enstitüsü Dergisi, Sa. 49, Erzurum 2013, s. 323-342.

Subaşı, Ömer, "Arap Fethinden Selçuklu Hâkimiyetine Artvin", Turkish Studies, Sayı: 7/3, 2012, s. 2329-2351.

Subaşı, Ömer, "Bizans İmparatorlarının Theodosiopolis ve Çevresindeki Faaliyetleri", Turkish Studies, Volume 5/3, 2010, s. 1827-1859.

Taberî, Ebû Ca'fer Muhammed b. Cerîr et-Taberî, Târîhu'r-Rusûl ve'l-Mulûk (Taberî Tarihi), c. 1-10, (Tahkik: Muhammed Ebu'l Fazl İbrahim), Beyrut 1967.

Tezcan Mehmet, Klasik ve Ortaçağ Dönemlerinde Karadeniz ve Kafkasya, Serander Yayınları, Trabzon 2012.

Tezcan, Mehmet, "İran Armeniası (Pers-Armenia), Tarihte Türkler ve Ermeniler (ilkçağ-Ortaçağ), c. I, TTK, Ankara 2014, s. 149-182.

Toumanoff, Cyril, "Armenia and Georgia", The Cambridge Medieval History, Vol. IV, The Byzantine Empire part I, Cambridge 1966, s. 593-637.

Toumanoff, Cyril, "Introduction to Christian Caucasian History II States and Dynasties of the Formative Period", Traditio, Vol. 17 (1961), s. 1-106.

Vâkıdî, Ebû Abdillâh Muhammed b. Ömer b. Vâkıd el-Vâkıdî el-Eslemî elMedenî, Fütûhu'ş-Şâm, c. 2, (Neşr: Abdüllatif Abdurrahman), Beyrut 1997.

Vasiliev, Alexander A., Bizans Imparatorluğu Tarihi, (Çev: Tevabil Alkaç), İstanbul 2016.

Vəlixanlı, Nailə, Arab Hilafeti ve Azerbaycan, Bakü 1993.

Ya'kūbî, Ebü'l-Abbâs Ahmed b. Ebî Ya'kūb İshâk b. Ca'fer b. Vehb b. Vâzıh el-Ya'kūbî, Târîhu'l-Ya'kūbî, c. 1-2, (Tahkik: Abdülemir Mehna), Beyrut 2010.

Yıldız, Hakkı Dursun, "Sâcoğulları", Doğuştan Günümüze Büyük İslam Tarihi, c. 6, İstanbul 1989, s. 81-136.

Yovhannēs, Drasxanakertc'i, History of Armenia, (Translation and Commentary: Rev. Krikor H. Maksoundian), U.S.A. 1987.

Zambaur, E. De, Manuel de Genealogie et de Chronologie Pour L'Histoire de L'íslam, Hanovre 1927.

Zehebî, Ebû Abdillâh Şemsüddîn Muhammed b. Ahmed b. Osmân ezZehebî et-Türkmânî el-Fârikî ed-Dımaşkî, Târîhu'l-íslâm ve vefeyâtü'l-meşâhîr ve'l-a'lâm, (Neşr: Beşşâr Avvâd Ma'rûf), Beyrut 2003. 